\title{
THE UNDERSTANDING OF HUDÛD ALLÂH IN THE QURAN: Study of Thematic-Contextual Interpretation
}

\section{مفهوه حلود الله في القرآذ الكريم : دراسة التفسير الموضوعي السياقي}

\section{Bakrei Mohammed Bakheet Ahmed}

University of the Holy Quran and Islamic Sciences, Sudan

E-mail: bakribkheet@gmail.com

\section{Abstract}

The term hudîd Allâh is one of those written in al-Quran al-Karim used for clarifying the laws. However, some people do not quite comprehend this term that their understanding is only limited to the law related to criminal (penalty), meanwhile Quran does not limit the term only for penalty. Therefore, the author chose the title to explain the hudûd Allâh term mentioned in Quran and its meanings in some parts using empirical and inductive methods in quoting opinions of mufassir both in the classic and contemporary generations. In this article, the author divides it into four discussions related to the theme in the verses. The crucial conclusion of this article is that the hudûd Allâh term in Quran never refers to criminal law such as the penalty for adultery, liquor, and the like. On the other hand, the term is to explain the laws of family matters, ahwal shahsiyah e.g. divorce, 'iddah (waiting period), filing divorce from the wife side, inheritance distribution, and general meaning on Allah's orders and prohibitions.

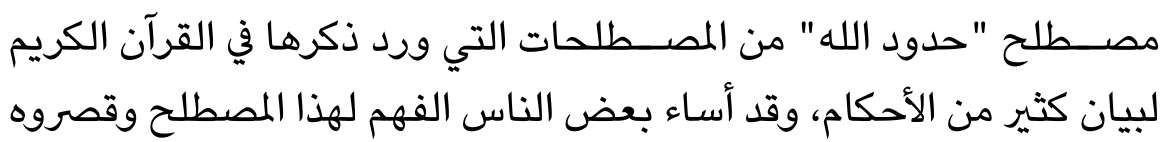


على العقويات الحدية فقط، والتي لم يقصـدها القرآن الكريم في كل المواضـع

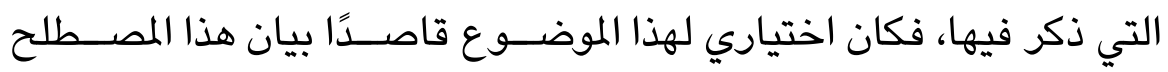

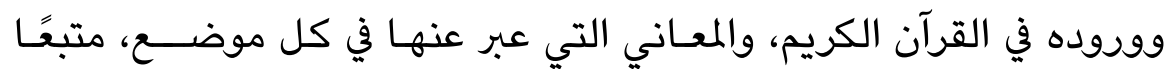

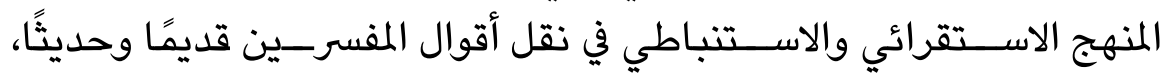

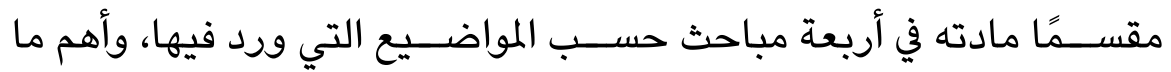

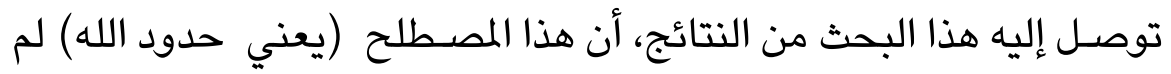
يرد في القرآن الكريم بمعنى العقوبات الحدية كحد الزنا وحد الخمر وغيرها،

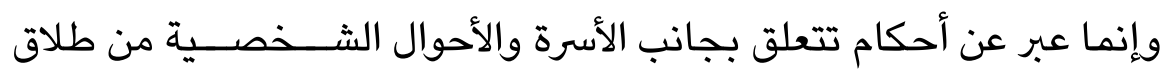

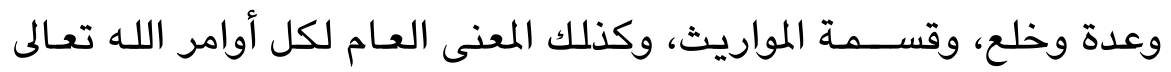
ونواهيه.

Keywords: ḥudûd Allâh; human understanding; rules

Received: August 27, 2020; Accepted: October 15, 2020

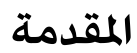

فإن معظم الناس يسيئون فهم مصطلح حدود الله الوارد في القرآن الكريم،

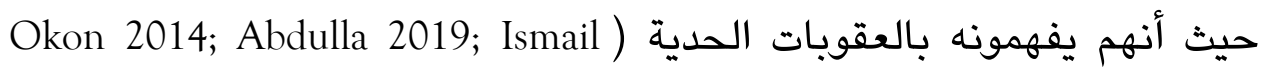

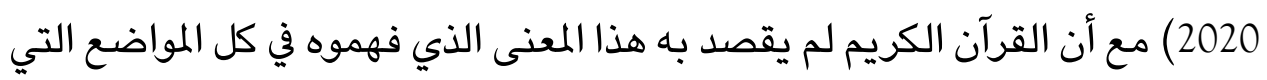
ورد فيها ذكره، لذلك كان مهمًا بيان المعاني التي قصدها القرآن من هذا المصطلح، وتصحيح المفهوم الخاطئ عند الناس والذي ترتبت عليه كثير من المواقف التي أثرت

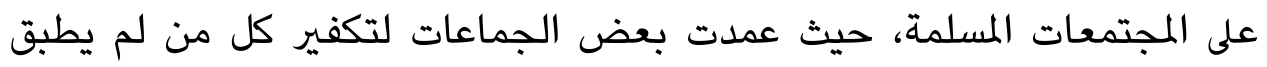

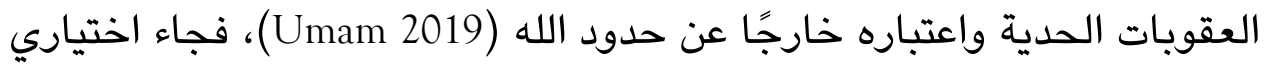

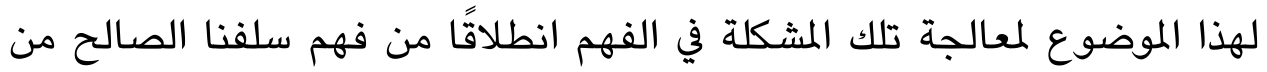

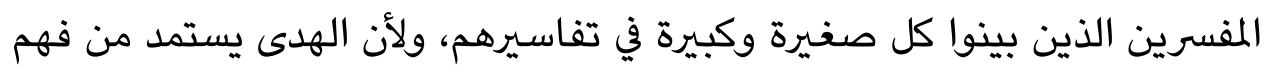

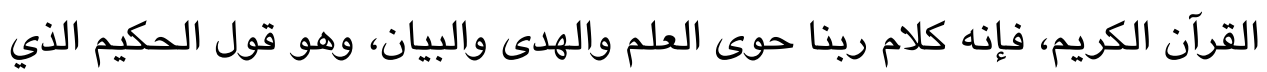

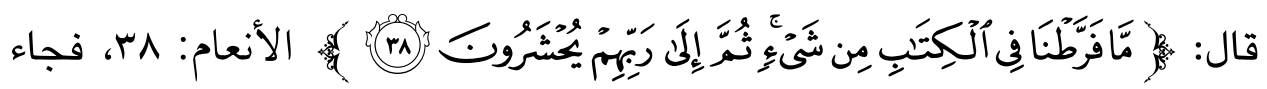


حاويًا لما يصلح حياتنا ويسعدنا بعد مماتنا، فكان حريًا بنا تدبره والتمسك بهديه،

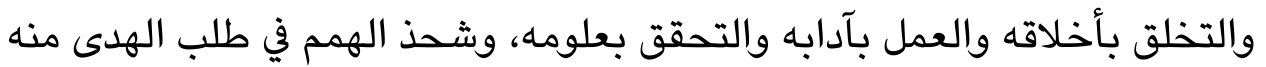

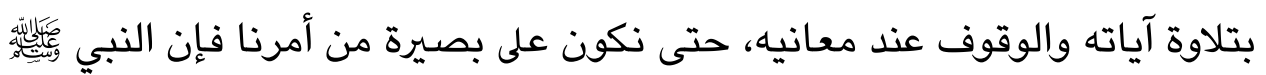

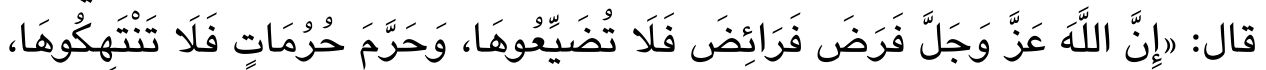

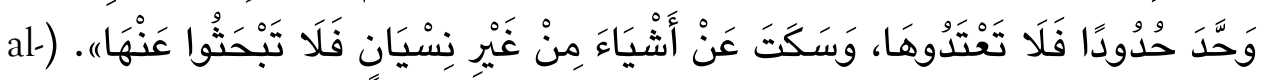

.(Dârquṭîi 2004, vol. 5, no. 4396, 325

فحتى نسلم لا بد أن نقف عند حدود الله، وقد يسأل أحدهم ما المقصود بحدود

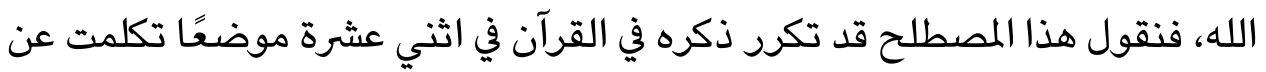
تفاصيل لأحكام تشريعية متنوعة ثم يأتي التعقيب بعدها والإشارة إلى ما فصل فئ فيها

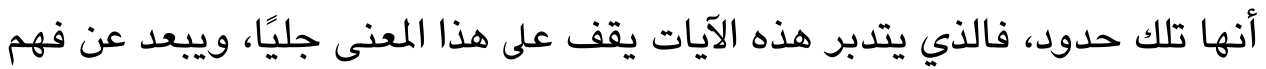

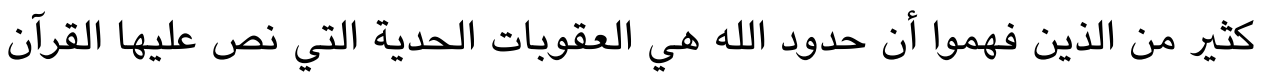

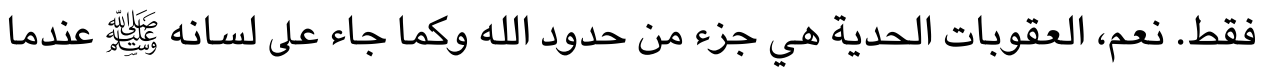

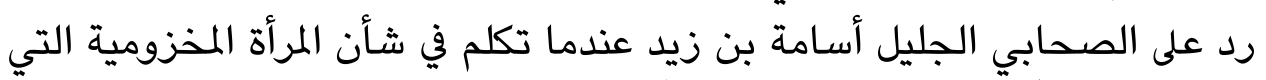

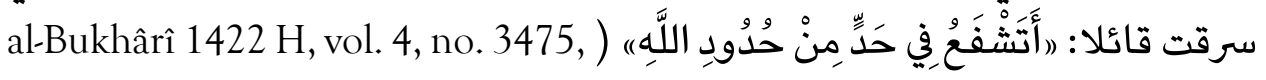

لكن هذا المصطلح يتسع حتى يشمل كل ما أحل الله تعالى وما حرم حتى

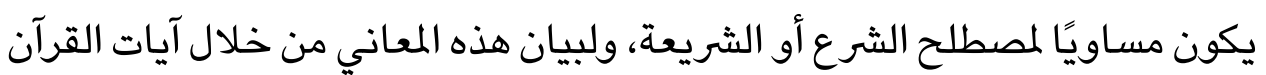

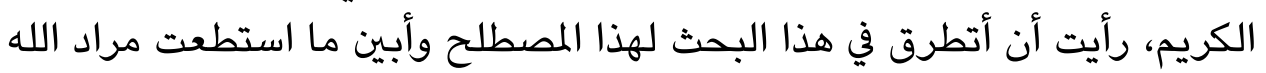
تعالى منه، وأصحح فهم من قصره على جزء منه، وسميته (مفهوم حدود الله في القرآن الكريم: دراسة التفسير الموضوعي السياقي) متبعًا المنهج الاستقرائي

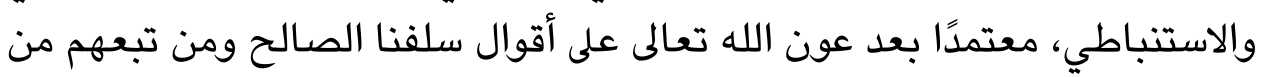
علمائنا المعاصرين، وقسمته بحسب ورود الآيات في المصحف إلى أربعة مباحت مباحث.

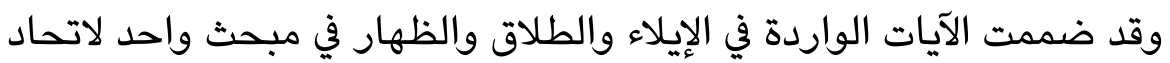
موضوعها فكلها صورة من صور تحريم الزوج لزوجته، والتي قد تقود إلى نتيجة وهي الفراق بين الزوجين من غير رجعة. وأسأل الله تعالى التوفيق والقبول. 


\section{معنى حدود الله في اللغة و مصطلح}

توطئة لهذا البحث أبدأ بييان معنى حدود الله في اللفة وفي مصطلح الشرع:

في اللغة

جاء في لسان العرب: (الحد: الفصل بين الشيئين لئلا يختلط أحدهما بالآخر، أو لئلا يتعدى أحدهما على الآخر، وجمعه حدود، وفصل ما بين كل شيئين: حد

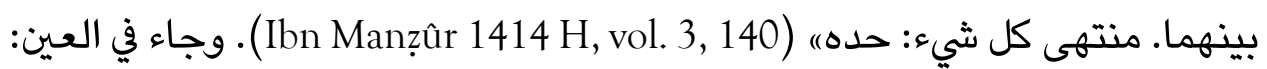

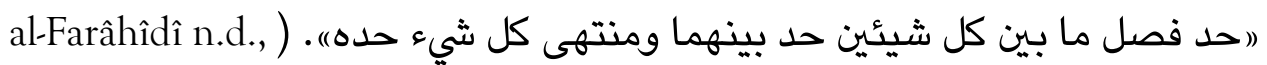

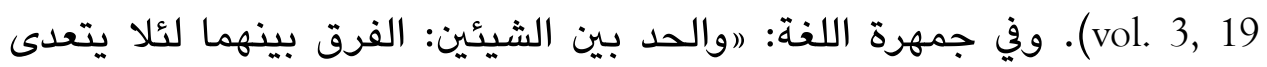

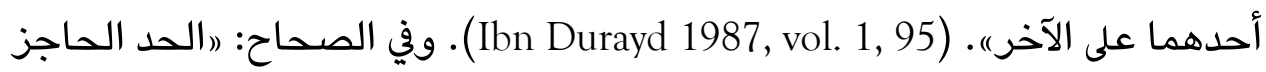
بين الشيئين. وحد الشيء منتهاه، تقول حددت الدار أحدها حدا. والتحديد مثله، والحد المنع). (al-Jawharî 1407 H, vol. 2, 462).

وبيّن وفصّل هذا المعنى الفيروزأبادي في بصائر ذوي التمييز فقال: الحَدّ:

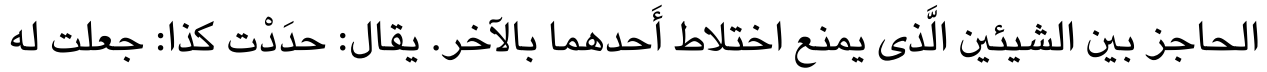

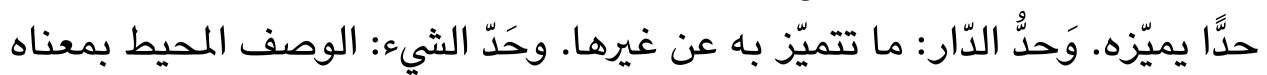

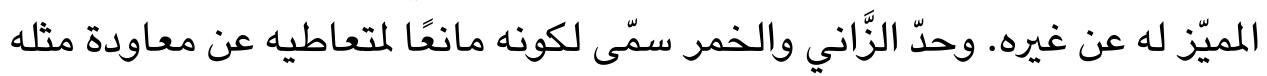

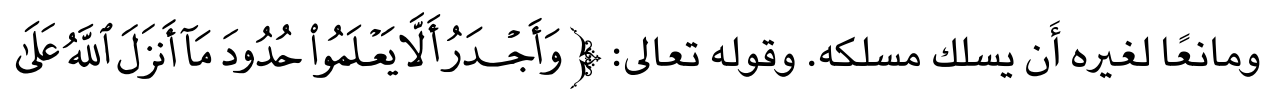

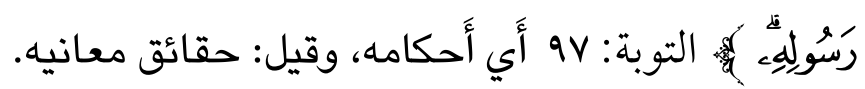

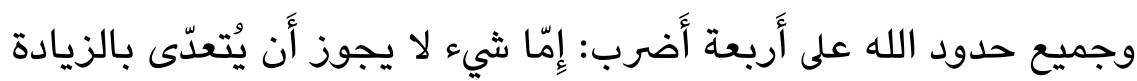

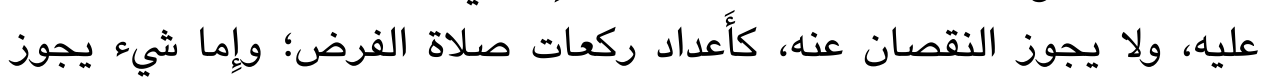

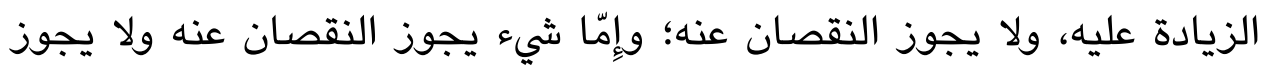

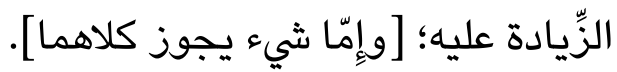
والحدود جاءَت في القرآن على سبعة أَوجهِ: الأَّْل حَدّ الاعتكاف لإِّلاص

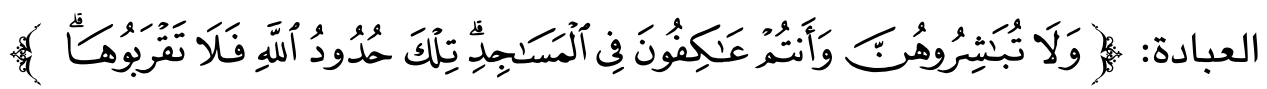

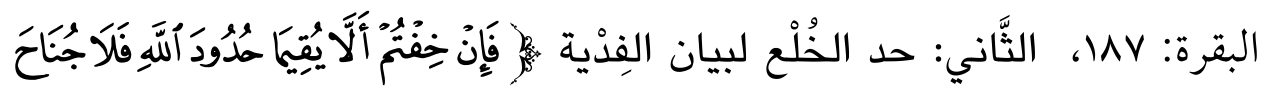




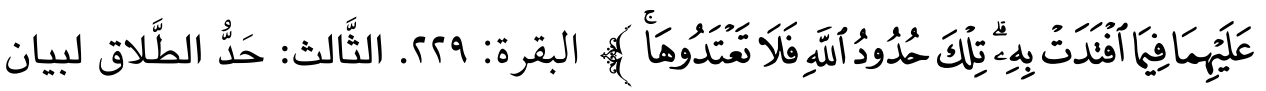

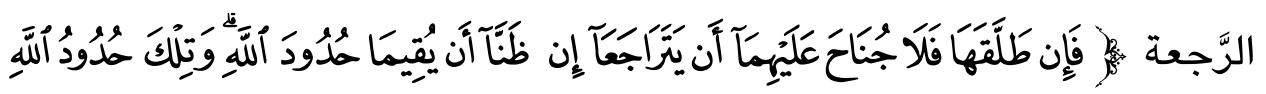

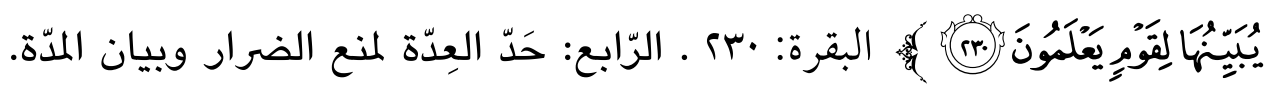

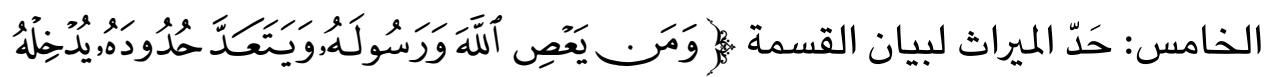

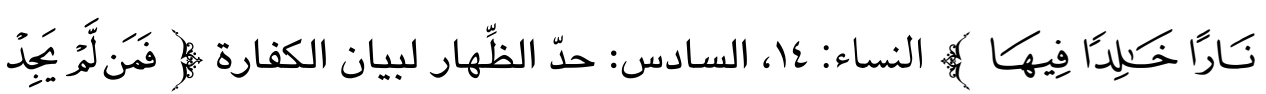

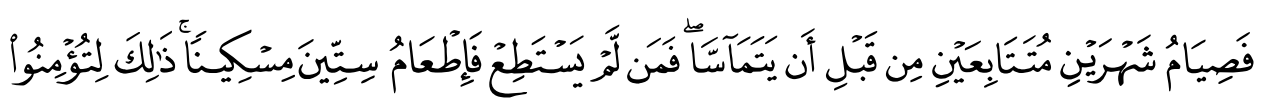

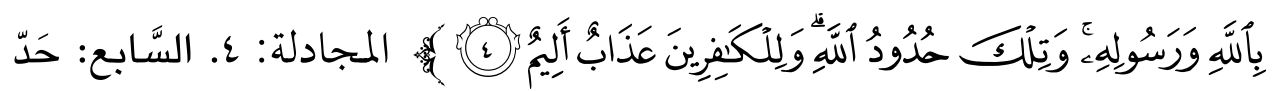

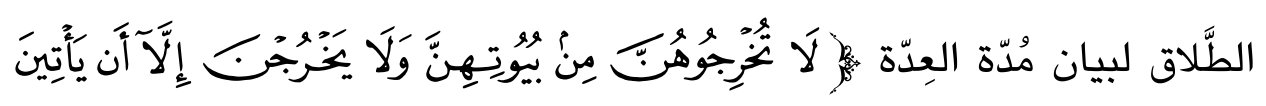

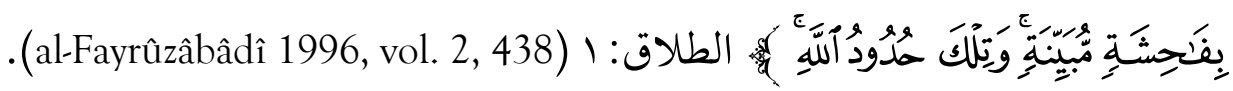
ومما تقدم نعرف أن الحد هو الحاجز والفاصل والمبين للأشياء حتى تكون المداء واضحةً وبينةً وكذلك هو المانع من الوصول المول إلى ما وراءه.

في الاصطلاح

جاء في النهاية في غريب الحديث: (الحدود هي محارم الله وعقوياته التي

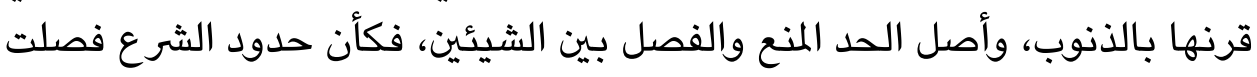

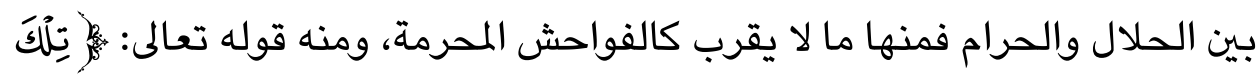

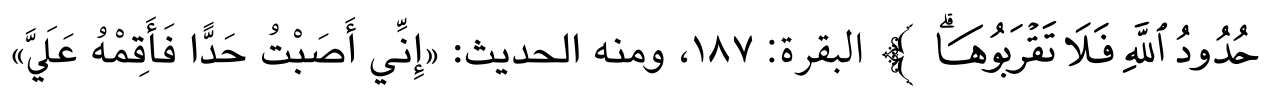
(al-Bukhârî 1422 H, vol. 8, no. 6823, 167) عقوية، (Ibn al-Athîr 1399 H, vol. 1, 352).

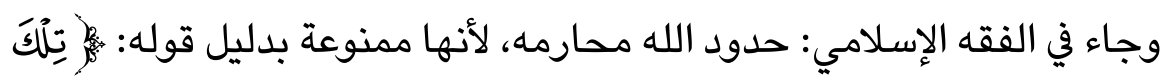

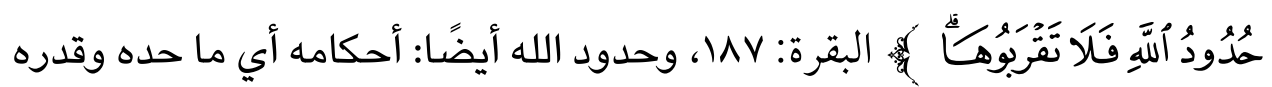


فلا يجوز أن يتعداه الإنسان، وسميت الحدود حدودًا لأنها تمنع عن التخطي إلى ما وراءها (al-Zuhaylî n.d., vol. 7, 5274).

وعند المالكية في بلغة السالك: (حدود الله ما حده ويينه من الأوامر بامتثال

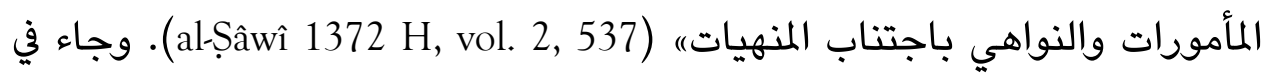
الفقه الحنفي: (الحد في الشرع، الحد: اسم لعقوية مقدرة يجب حقا للهاب لله تعالى ولهذا لا يسمى به التعزير؛ لأنه غير مقدر ولا يسمى به القصاص؛ لأنه حق العباد وهذا؛

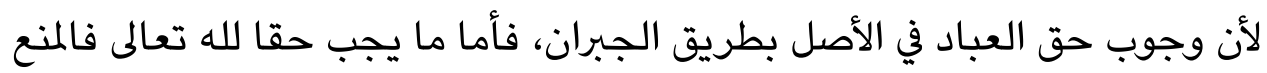

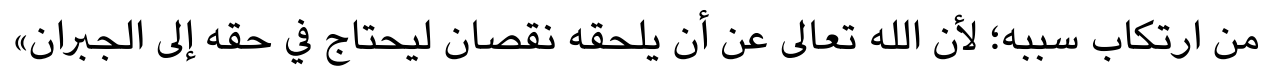
.(al-Sarakhsî 1993, vol. 9, 36)

وأما عند الشافعية فقال الماورديُّ: (رأما الحدود تعريفها: فهي عقويات زجر

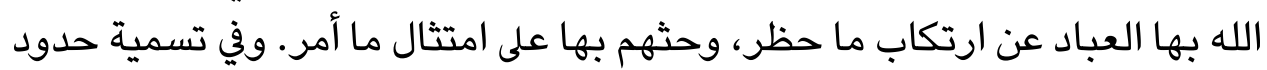

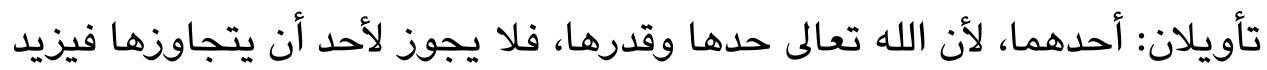

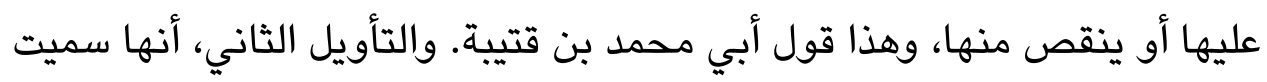

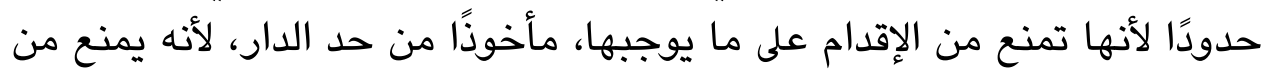

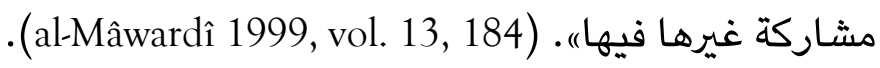
وفي الفقه الحنبلي: (الحدود جمع حد وهو في الأصل المنع والفصل بين شيئين

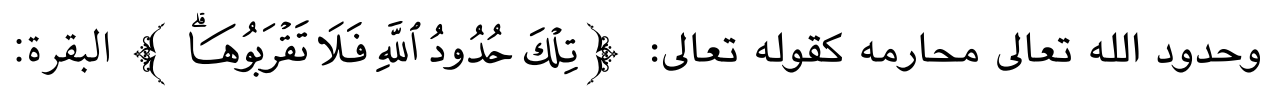
VAV وحدود الله تعالى أيضًا ما حده وقدره فلا يجوز أن يتعدى كالمواريث المعينة وتزويج الأربع ونحو ذلك مما حده الشرع فلا يجوز فيه الزيادة ولا النقصان، قال

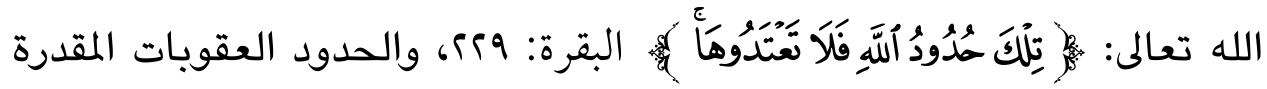
يجوز أن تكون سميت بذلك من الحد المنع لأنها تمنع من الوقوع في مثل ذلك الذنب

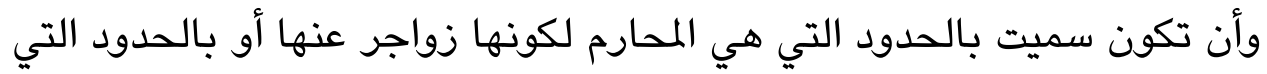

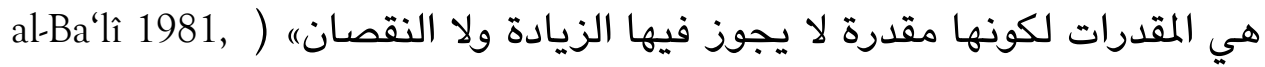


ومما تقدم نعرف أن الحدود شرعا هي ما حده الله تعالى ويينه لعباده من المأمورات والمنهيات، وما قدره من العقويات زجرًا لأهل المعاصي.

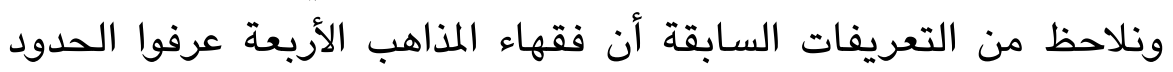

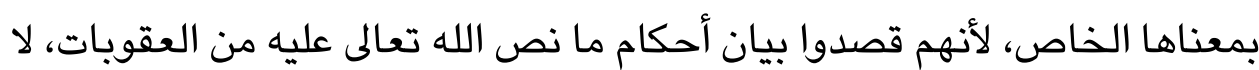
حصرًا لمعناها فيها فقط كما درج عليه كثير من الناس، خاصة بعض الهما الجماعات التي تتبنى الدعوة لتطبيق حدود الله.

\section{أحكام في ليالي رمضان}

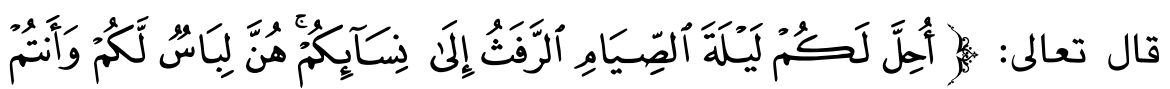

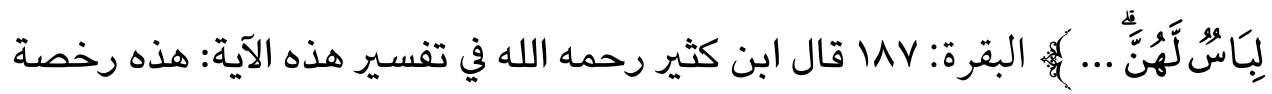
من الله تعالى للمسلمين، ورفع لما كان عليه الأمر في ابتداء الإسلام، فإنه كان إذا أفطر

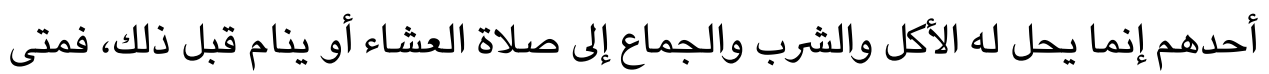

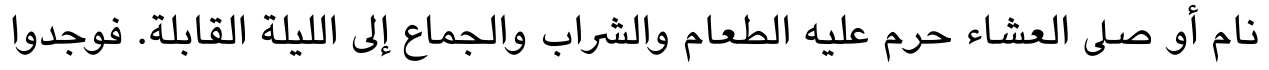
من ذلك مشقة كبيرة. والرفث هنا الجماع (Ibn Kathîr 1420 H, vol. 1, 510).

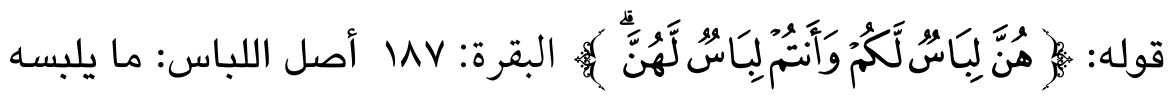
الإنسان مما يواري جسده، ثم المرأة تسمى لباس الرجل والرجل لباس المرأة، لانضمام جسد كل واحد منهما إلى جسد صاحبه، حتى يصير كل واحد منهما لصاحبه كالثوب الذي يلبسه، فلما كانا يتلابسان عند الجماع سمي كل واحد منهما لباسًا للآخر. (al-Wâhidî 1430 H, vol. 3, 599).

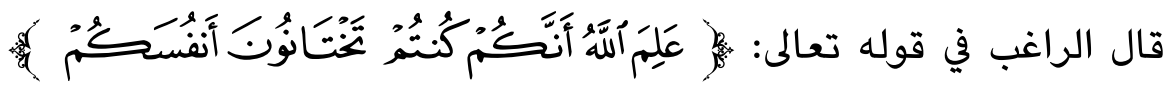
البقرة: MVV الاختيان مراودة الخيانة وتخصيصه من دون قوله تخونون لفائدة، وهي أن المخاطبين لم يكونوا كلهم خانوا وكلهم أو جلهم قد اختانوا، لأن الاختيان هو أن تتحرك الشهوة وتدعوه (al-Asfahânî 1999, vol. 1, 399). 
ونقل صاحب اللباب تفصيل القول عن ابن الخطيب، فقال: قال ابن الخطيب:

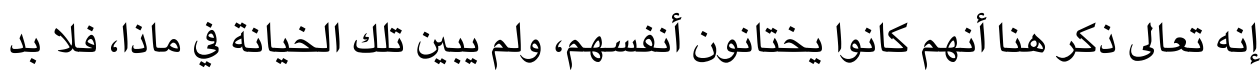

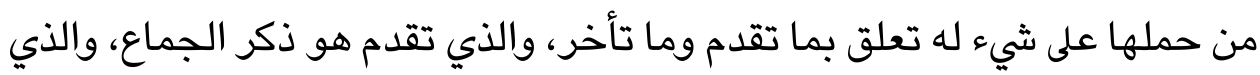

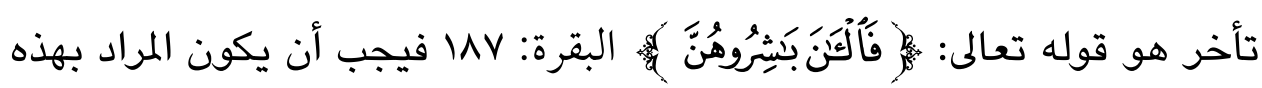
الخيانة الجماع وها هنا قولان:

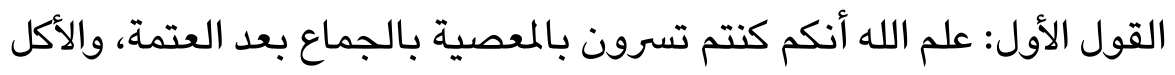
بعد النوم، ترتكبون المحرم من ذلك، وكل من عصى الله فقد خان نفسه، وعلى هذا

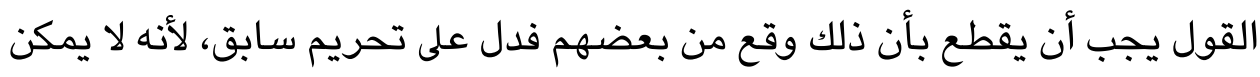

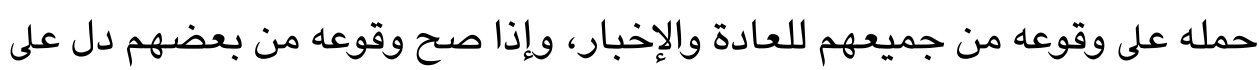
تحريم سابق.

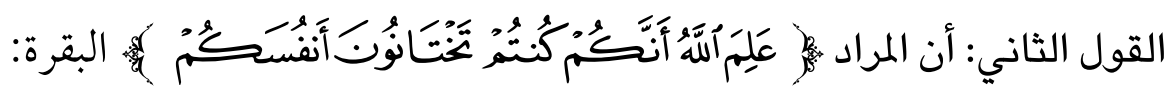
MV لو دامت تلك الحرمة، فمعناه: أن الله يعلم أنه لو دام ذلك التكليف الشاق، al-Hanbalî 1998, vol. ) لوقعوا في الخيانة، وعلى هذا التقدير ما وقعت الخيانة. . $(3,309-10$

وقد ذكر الإمام الطبري رحمه الله ما يؤيد القول الأول بقوله: وكانت خيانة

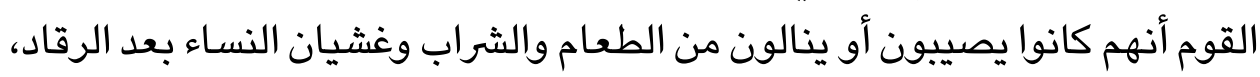
وكانت تلك خيانة القوم أنفسهم ثم أحل الله لهم بعد ذلك الطعام الطعام والشراب وغشيان النساء إلى طلوع الفجر (al-Ṭabarî 1420 H, vol. 3, 501).

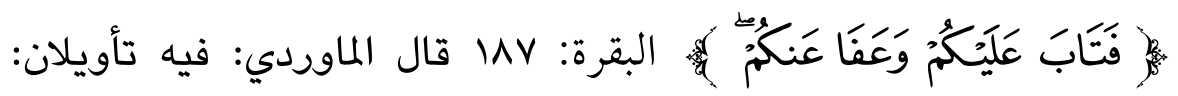
أحدهما: العفو عن ذنوبهم، والثاني العفو عن تحريم ذلك بعد النوم ( al-Mâwardî

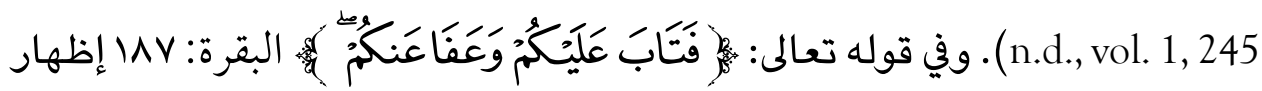
لرحمة الله بهم وفضله عليهم، إذ عاد عليهم برحمته، حيث أطلق نفوسهم من هذا الحرج الذي كانوا يعيشون معه في هم وقلق (al-Khatîib n.d., vol. 1, 205). 


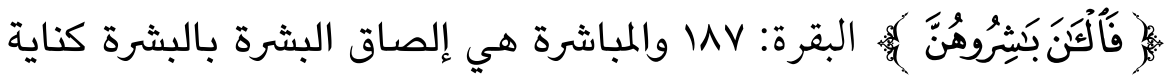

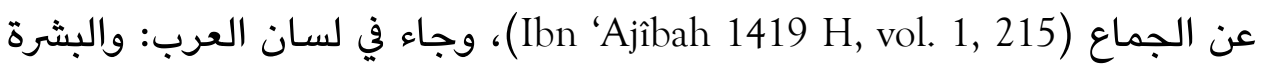

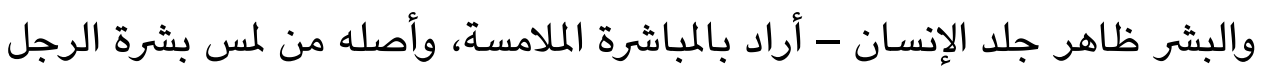

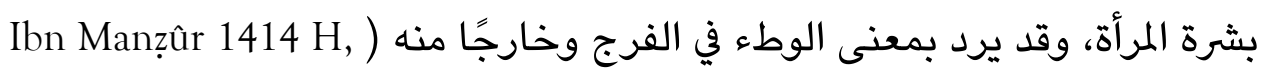
.(vol. 4, 61

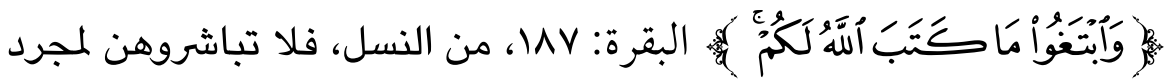

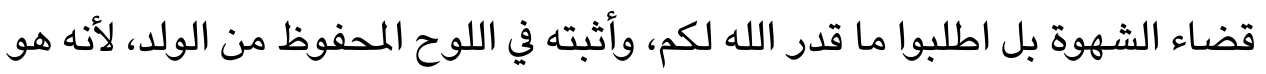

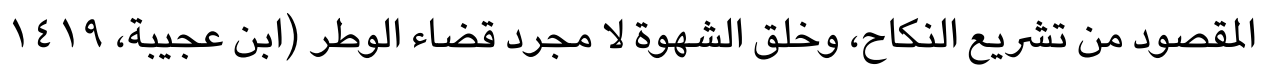

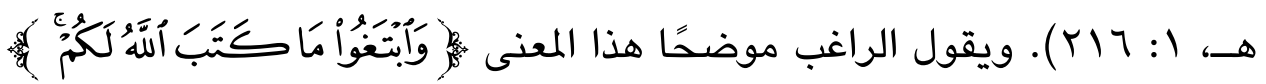

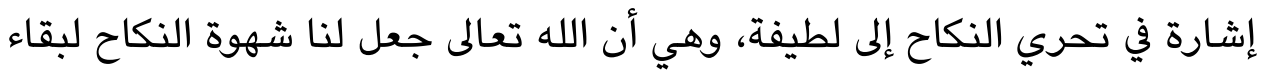

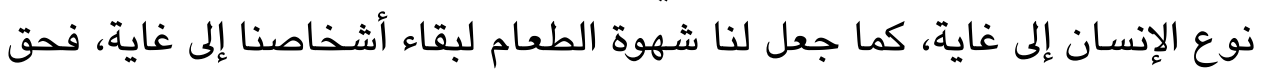

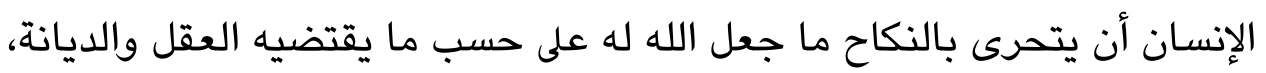

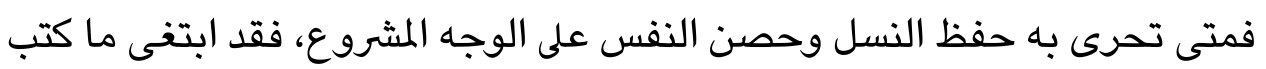
الله له (al-Asfahânî 1999, vol. 1, 399).

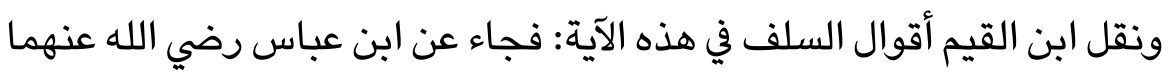

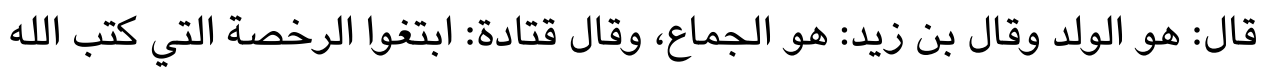

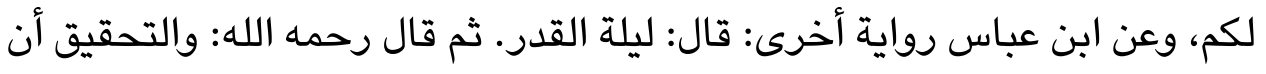

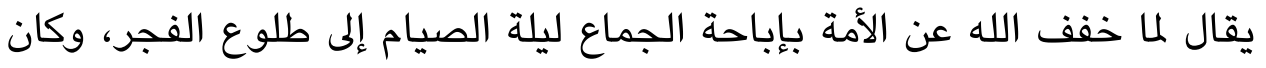

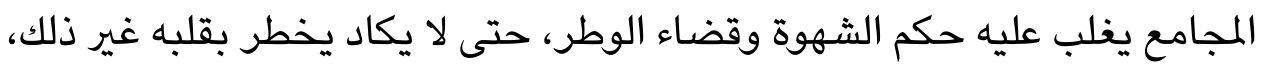

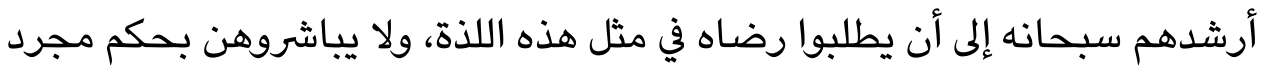

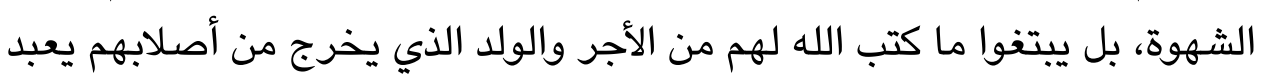

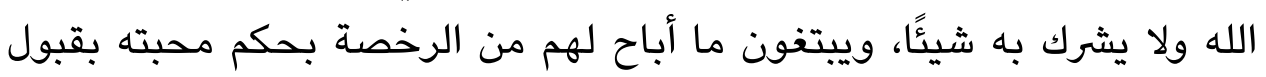

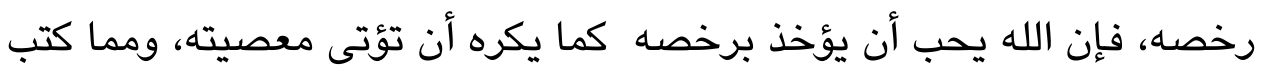
الله لهم: ليلة القدر، فأمروا أن يبتغوها. 
لكن يبقى أن يقال: فما تعلق ذلك بإباحة مباشرة أزواجهم؟ فيقال: فيه إرشاد

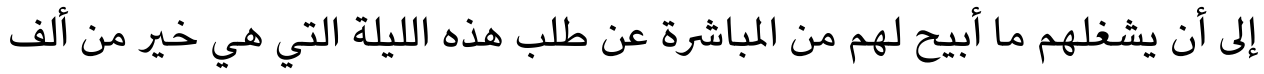

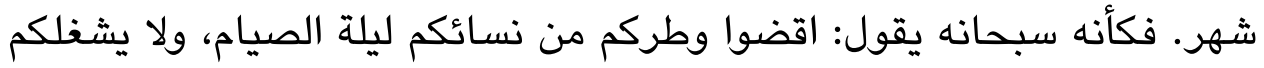

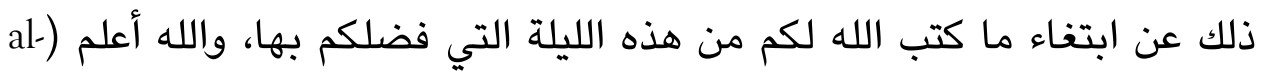
.(Jawziyah 1410 H, vol. 1, 147

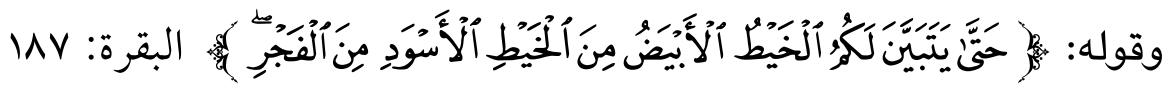
هو تشبيه بليخ، والمراد بالخيط: هو المعترض في الأفق، لا الذي هو كذنب السرحان

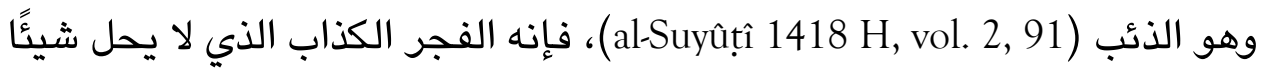
ولا يحرمه.

وذكر الشوكاني: أن المراد بالخيط الأسود: سواد الليل، والتبيين: أن يمتاز أحدهما عن الآخر، وذلك لا يكون إلا عند دخول وقت الفجر، وقوله: ثم أتموال الصوال الصيام

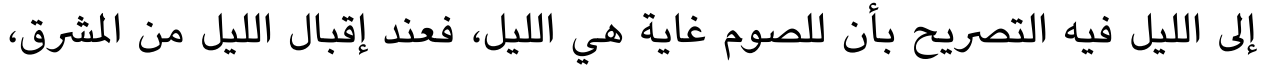

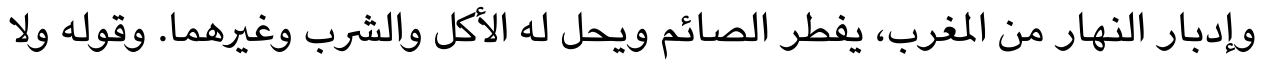

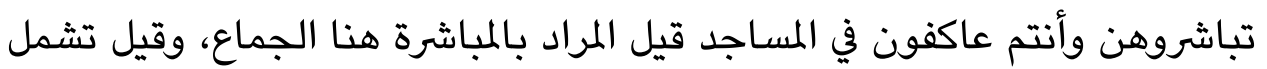

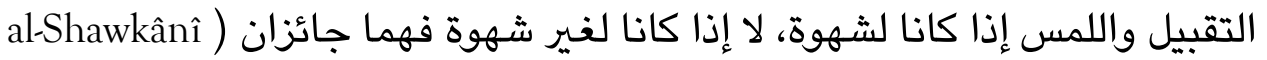
.(1414 H, vol. 1, 214

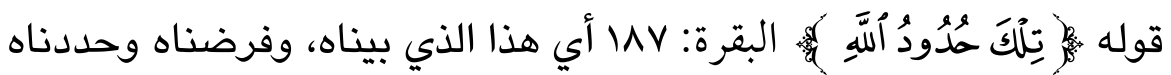
من الصيام، وأحكامه وما أبحنا فيه وما حرمنا وذكر غاياته ورخصه وعزائمه،

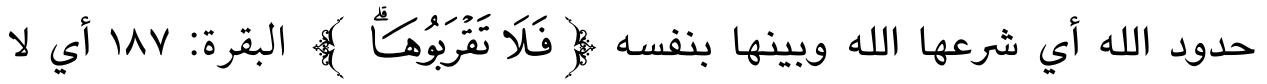
تجاوزوها، وتعتدوها (Ibn Kathîr 1420 H, vol. 1, 520).

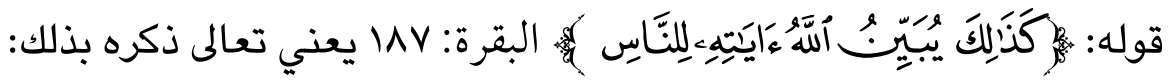
كما بينت لكم أيها الناس واجب فرائضي عليكم من الصوم، وعرفتكم حدوده وأوقاته وما عليكم منه في الحضر، وما لكم فيه في السفر والمرض، وما اللازم لكم تجنبه في في في حال اعتكافكم في مساجدكم، فأوضحت جميع ذلك لكم فكذلك أبين أحكامي، وحلالي 
وحرامي وحدودي وأمري ونهي في كتابي وتنزيلي، على لسان رسولي صلى الله عليه

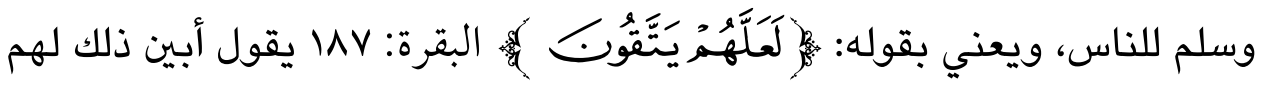
ليتقوا محارمي ومعاصيَّ، ويتجنبوا سخطي وغضبي، بتركهم ركوب ما أبين لهم في

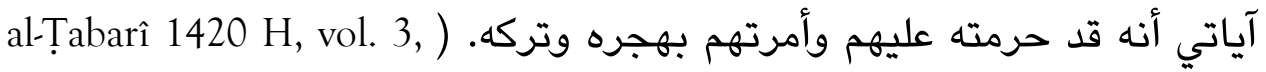
.) (547

يتضح لنا مما تقدم مما استعرضناه من أقوال المفسرين أن حدود الله في هذه الآية قصد بها الأحكام التي فصلها الله تعالى وبينها في شأن الصيام وحدودها، وأحكام الاعتكاف وما يلزم فيه من شروط، وهذه الأحكام منها ما هو فرض ولهابه واجب، ومنها ما هو مستحب ومسنون، ومنها ما هو رخصة وتوسعة ومنها ما هو مباح فتلك هي حدود الله التي جعلها الله علامات هادية ترشد السالكين وتنير لهم الطريق إلى ربهم الكريم فيتحققوا بتقواه وينالوا رضاه.

\section{تصريم الزوجة}

شرع الإسلام الزواج عقدًا دائمًا غير مؤقت، لا يقطعه إلا هادم اللذات، أو أبغض الحلال إلى الله وهو الطلاق، ويالزواج يحل للرجل كل شيء من زوجة، في

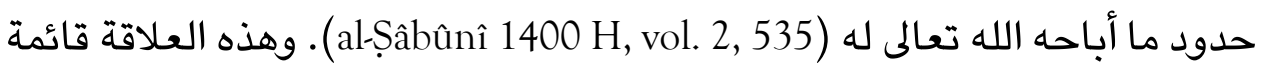
على المودة والرحمة، ولكن قد ينتاب هذه العلاقة شيء من سوء التفاهم بين الزوجين

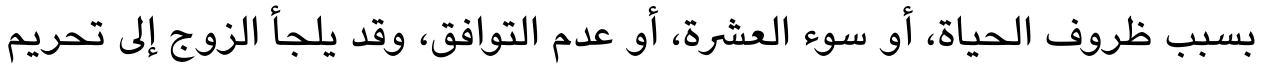
هذه العلاقة التي أحلها الله تعالى له، وصور تحريم الزوجة ثلاث الثرة في الإسلام، بالإيلاء وهو الحلف أو بالطلاق أو بالظهار، وفي حالة واحدة تستطيع الزوجة إنهاء علاقتها

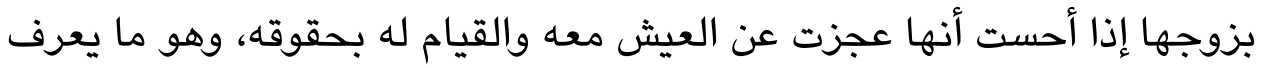

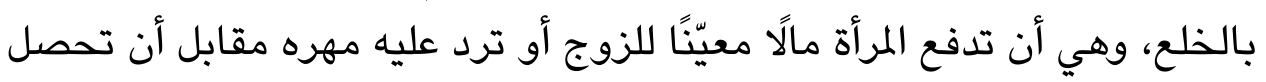
منه على الطلاق والمفارقة.

وقد فصل الإسلام هذه الأحكام في كتابه الكريم، مبينًا أوامره ونواهيه وما يجب على الزوجين فعله إذا حصل تحريم بأحد هذه الثلاث، وقد بدأت الآيات هنا 


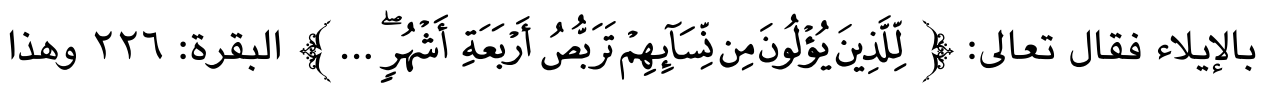

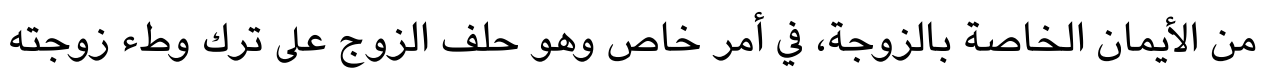

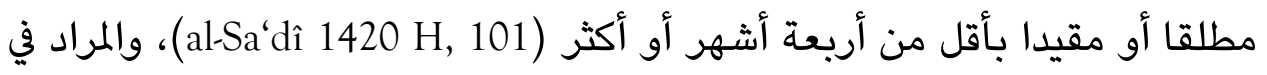

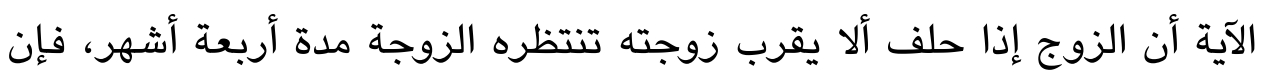

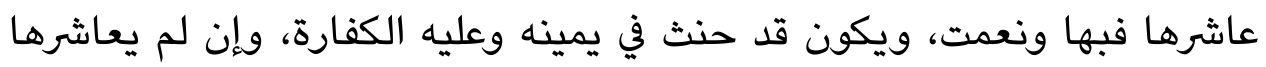

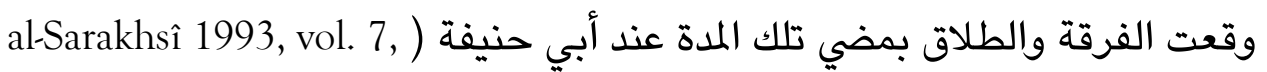

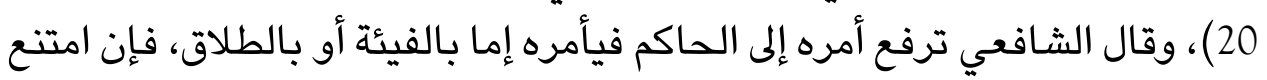

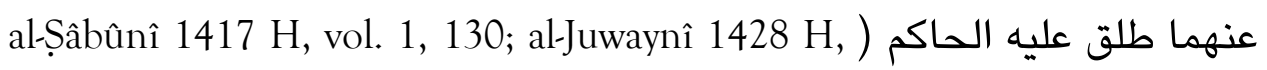
.(vol. 14, 383 والطلاق له أحكام كثيرة فصلت في كتب الفقه ولا يسع المجال لسردها، والذي

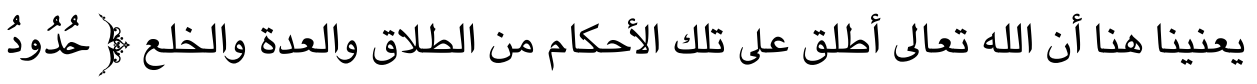

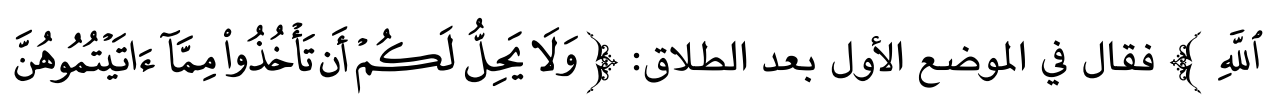

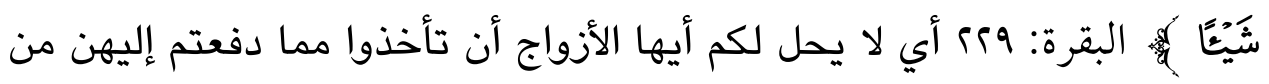

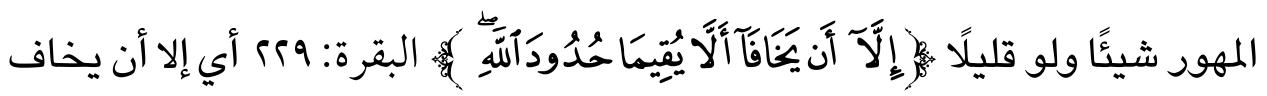

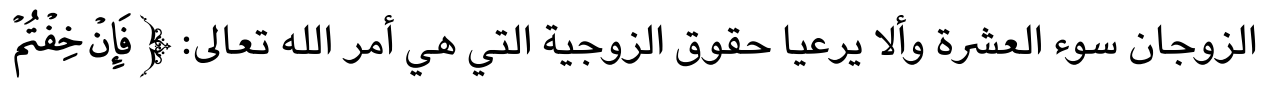

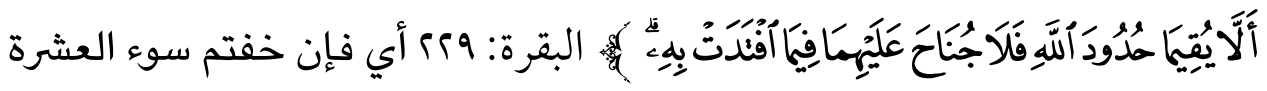

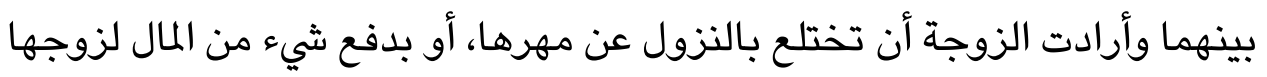

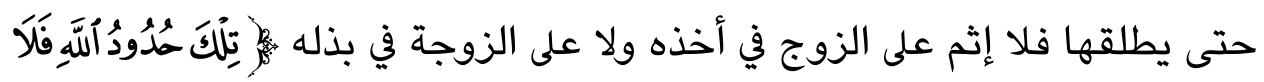

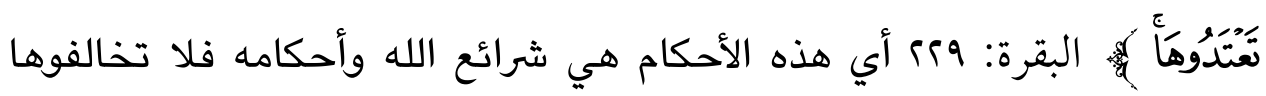

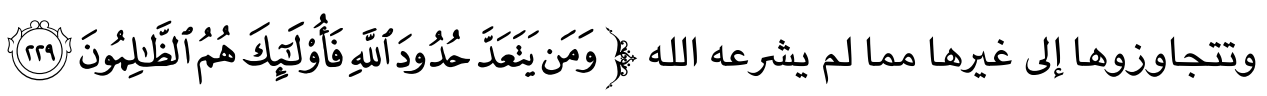

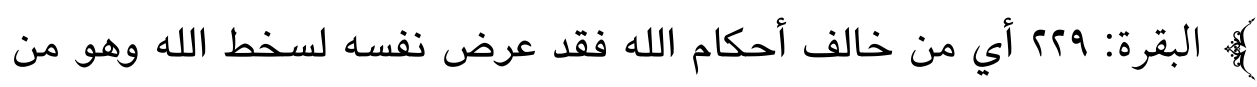
الظالمين المستحقين للعذاب الشديد (al-Ṣâbûnî 1417 H, vol. 1, 131). 
فحدود الله هنا في هذا الموضع هي عبارة عن العشرة بالمعروف التي أمر الله

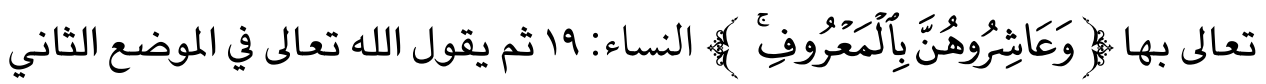
وهو بعد زواج الزوجة من رجل آخر بعد انقضاء عدتها وطلاقها من ذلك الرجل

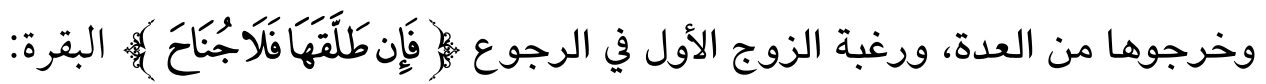

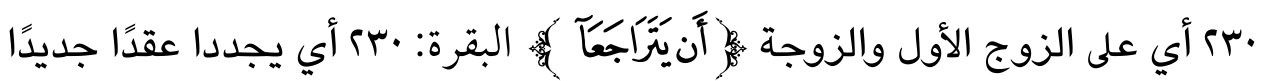
بينهما، لإضافته التراجع إليهما فدل على اعتبار التراضي.

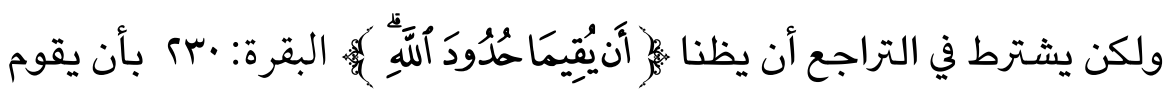
كل منهما، بحق صاحبه، وذلك إذا ندما على عشرتهما السابقة الموجبة للفراق، وعزما

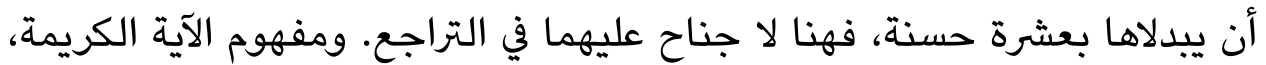

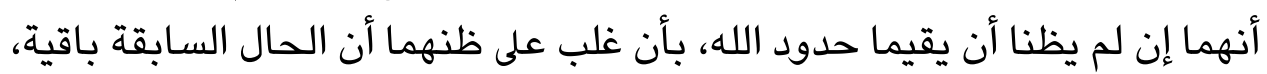

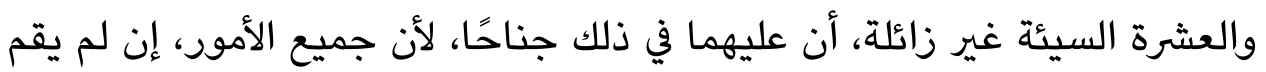
فيها أمر الله، ويسلك بها طاعته، لم يحل الإقدام عليها. ولما بين تعالى هذه الأحكام

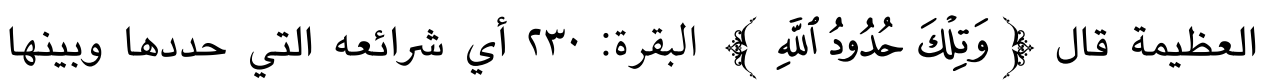

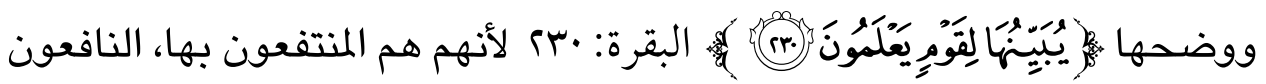
لغيرهم. وفي هذا من فضيلة أهل العلم، ما لا يخفى، لأن الله تعالى جعل تبيينه لحدوده، خاصا بهم، وأنهم المقصودون بذلك، وفيه أن الله تعالى يحب من لان عباده، معرفة حدود ما أنزل على رسوله والتفقه بها (al-Sa'dî 1420 H, 102).

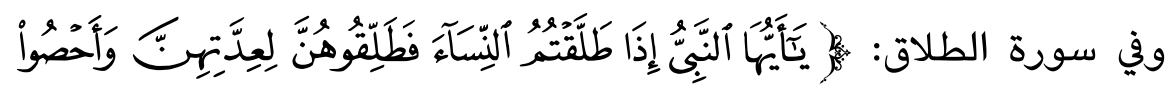

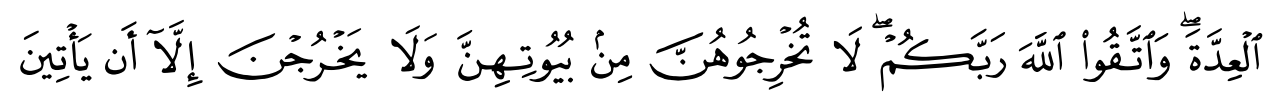

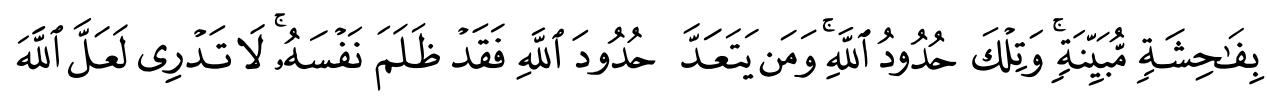

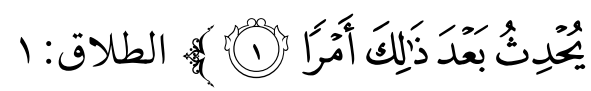


بينت الآيات أن الطلاق لا بد أن يقع على طهر وليس في حيض، وألا تخرج من

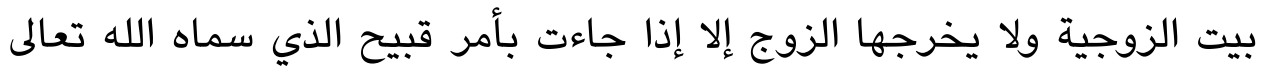
فاحشة مبينة، وبينها الإمام الطبري رحمه الله بقوله: عنى بالفاحشة في هذا الموضع:

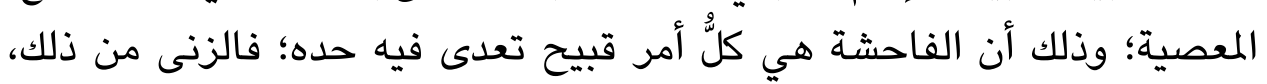

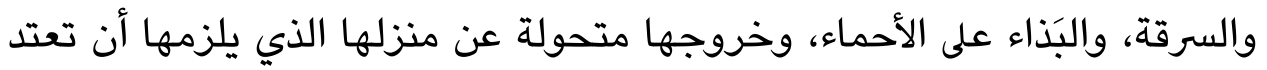

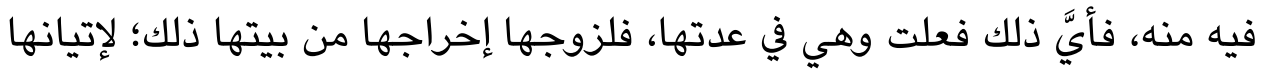

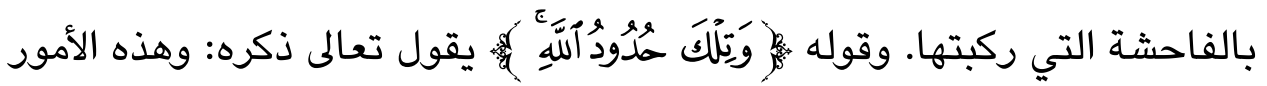

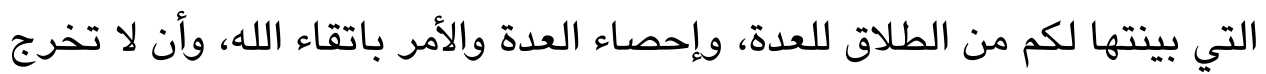

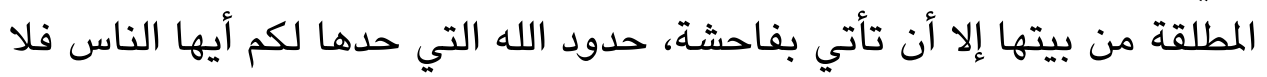

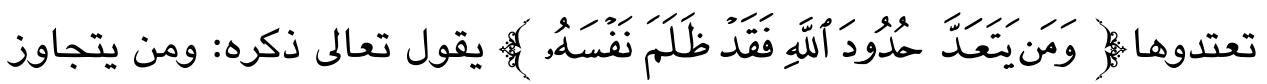
حدود الله التي حدها لخلقه فقد ظلم نفسه، يقول: فقد أكسب نفسه وزرا فصار بذلك لها ظالما، وعليها متعديًا (al-Ṭabarî 1420 H, vol. 23, 441).

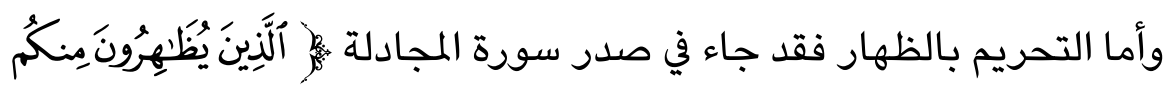

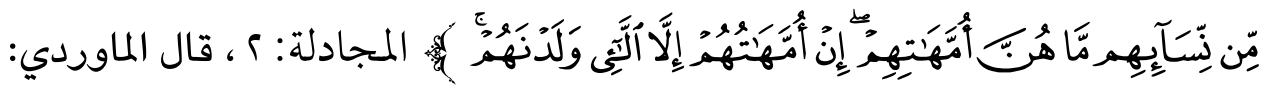
الظهار هو قول الرجل لامرأته "أنت علي كظهر أمي" سمي ظهارًا لأنه قصد تحريم ظهرها عليه، وقيل لأنه قد جعلها كظهر أمه، وقد كان في الجاهلية طلاقًا ثلاثًا لا

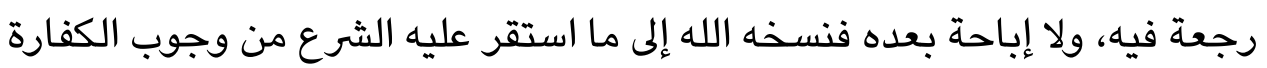
فيه بالعود (al-Mâwardî n.d., vol. 5, 448). وقد حرم الله تعالى الظهار وغلّظ كفارته حتى لا يتهاون الناس بهذا الأمر

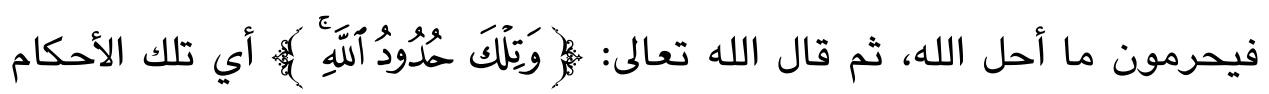
المذكورة من تحريم الظهار، وإيجاب العتق للواجد، وإيجاب الصوم لغير الواجد إن

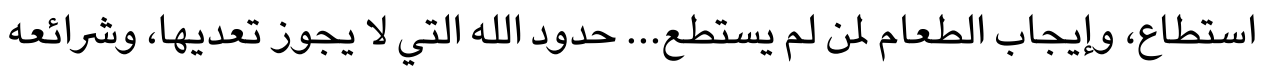

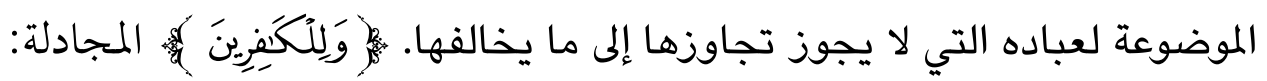




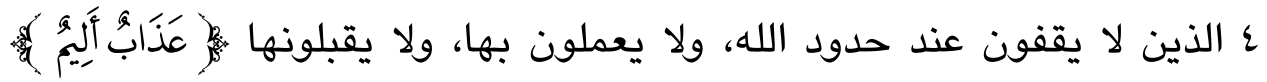
المجادلة: ع أي مؤلم موجع (al-Hararî 1421 H, vol. 29, 26). مما تقدم تبين لنا أن الآيات السابقة قد تحدثت عن تحريم الزوج ما أحله

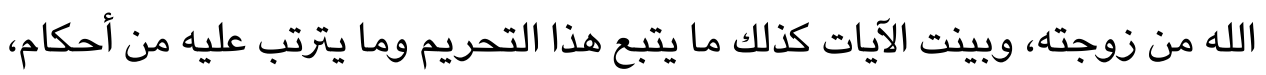

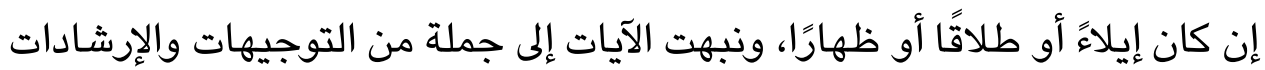
التي ترمي لإقامة العدل ورفع الظلم والضرر الذي يقع أحيانا على المرأة جراء سوء استخدام الرجل لهذا الحق عندما لا ينضبط بأوامر الله، وكذلك نهت الآيات النساء

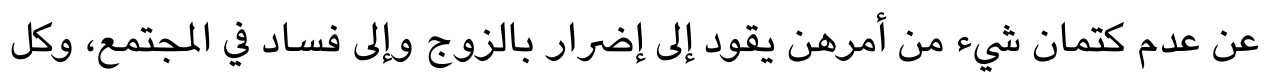

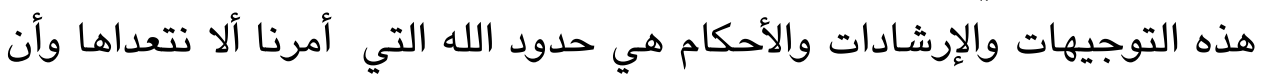
نسعى لتعلمها لنقف عندها.

\section{الميراث}

قال تعالى:

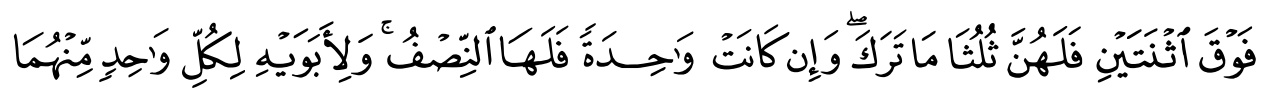

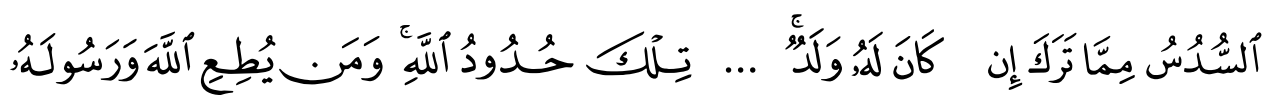

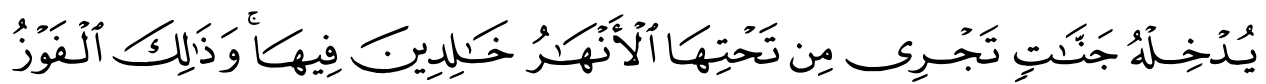

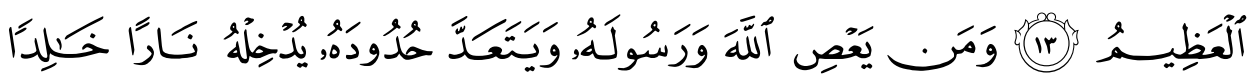

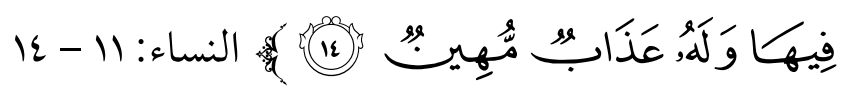
هذه الآيات تتكلم عن الميراث وهو علم جليل تكفل الله بييانه وإيضاحه، لأن أهل الجاهلية كانوا ظالمين في أحكامهم، وكانوا يظلمون النساء والأطفال، كانوال الا

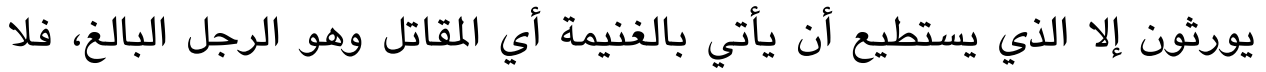

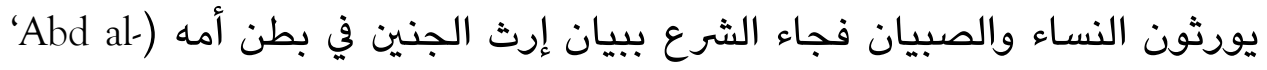
(Ghaffâr n.d. 
لأن الوصاية هي الأمر بما فيه نفع المأمور، وفيه اهتمام الأمر لشدة صلاحه، ولذلك

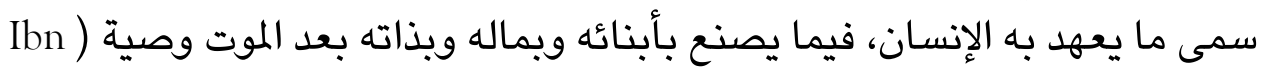
.('Âshûr 1984, vol. 4, 56 والفرائض التي فرضها الله في كتابه ستة، النصف، والربع والثمن، والثلثان، والثلث، والسدس. والوارثون من الرجال عشرة: الابن، وابن الابن وإن سفل، والأب

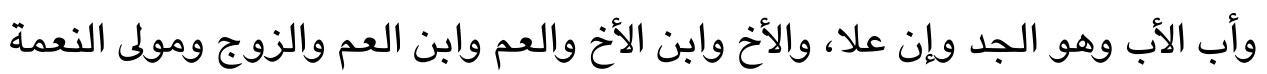

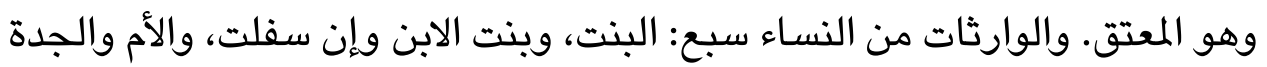

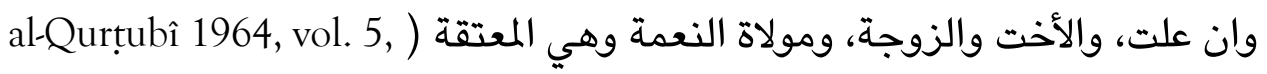

قال صاحب مفاتيح الغيب: اعلم أنه تعالى أورد أقسام الورثة في هذه الآيات

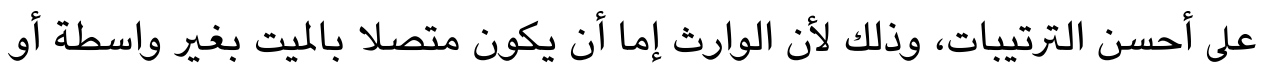

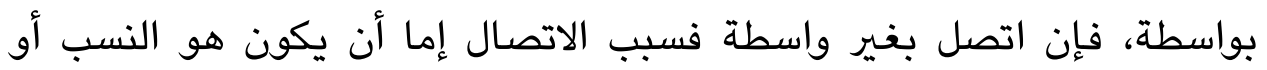

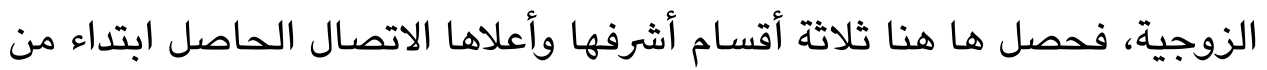

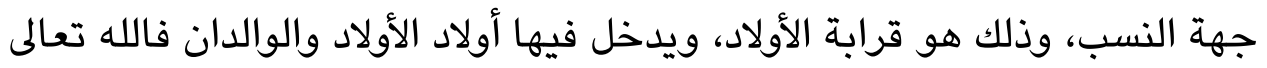
قد قدم هذا القسم، وثانيها الاتصال الحاصل ابتداء من جهة الزوجية، وهذا القسم متأخر في الشرف عن القسم الأول لأن الأول ذاتي وهذا الثاني عرضي والذاتي أثرف الثاه من العرضي، وهذا القسم هو المراد من هذه الآية التي نحن الآن تفسيرها. وثالثها:

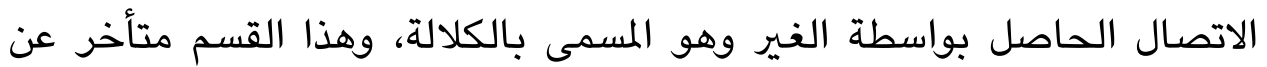

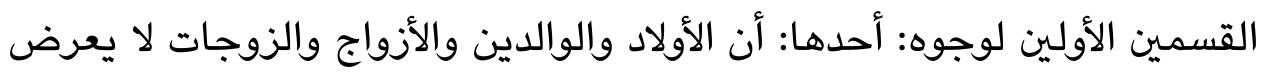

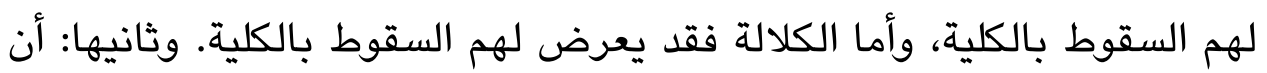
القسمين الأولين ينسب كل واحد منهما إلى الميت بغير واسطة، والكلالة تنسب إلى والى

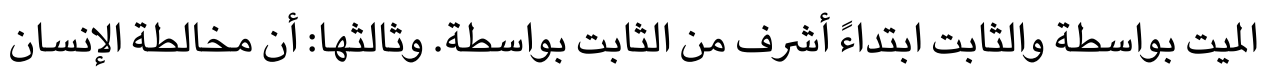
بالوالدين والأولاد والزوج والزوجة أكثر وأتم من مخالطته بالكلالة. وكثرة المخالطة مظنة الألفة والشفقة، وذلك يوجب شدة الاهتمام بأحوالهم، فلهذه الأسباب الثلاثة وأشباهها أخر الله تعالى ذكر مواريث الكلالة عن ذكر القسمين الأولين فما أحسن وندان هذا الترتيب وما أشد انطباقه على قوانين المعقولات. (al-Râzî 1420 H, vol. 9, 520). 
ثم يأتي التعقيب من الله تعالى بعد بيان هذه الأحكام، وهذه الأنصبة من

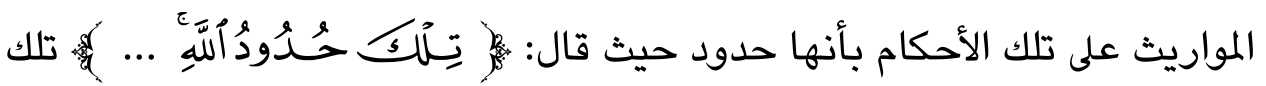
الفرائض وتلك التشريعات التي شرعها الله وفق علمه وحكمته هي أحكام الله التي

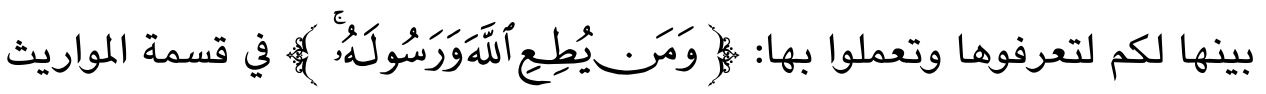

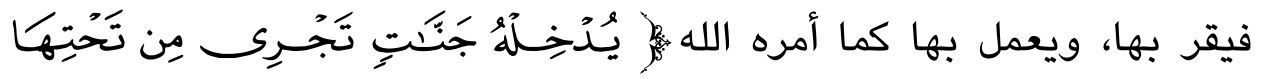

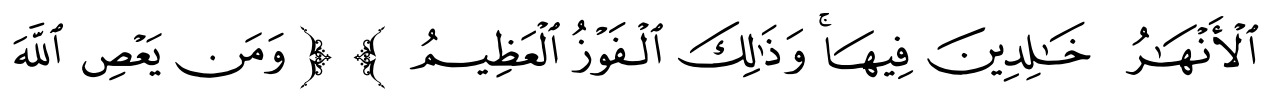

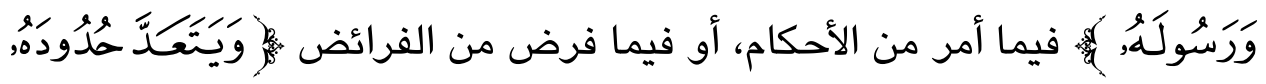

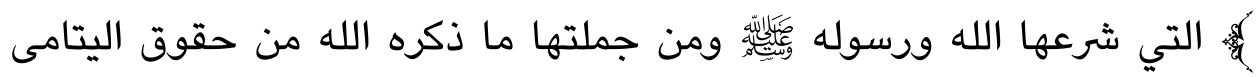

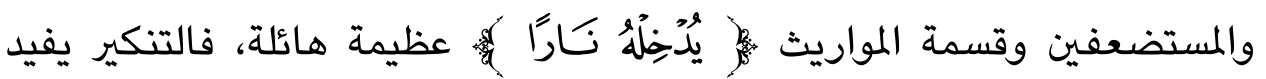

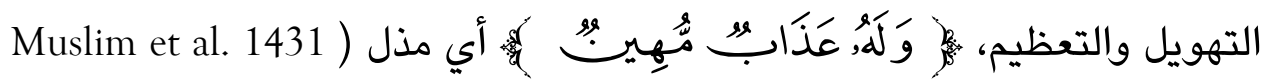
.(H, vol. 2, 46

فالفرائض التي بينها الله تنظم العلاقات الأسرية، والعلاقات الاجتماعية

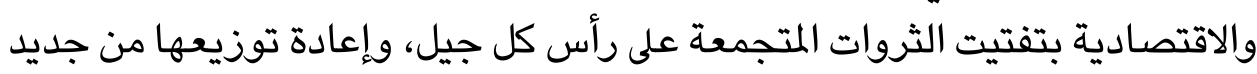

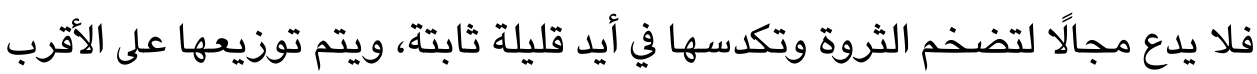

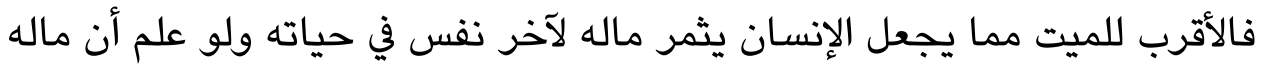

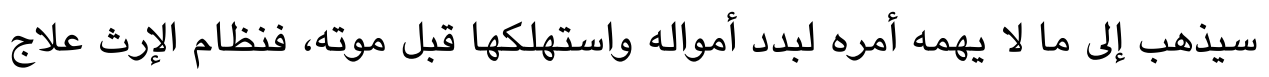
اقتصادي، ومودة أسرية، ورابطة اجتماعية (Muslim et al. 1431 H, vol. 2, 47). وبعد استعراضنا للآيات السابقة نرى حكمة الله تعالى ورحمته بالإنسان،

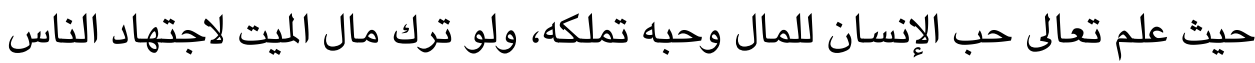

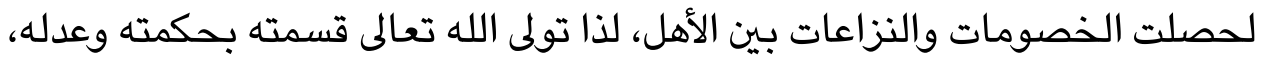

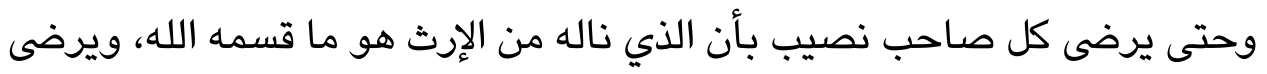

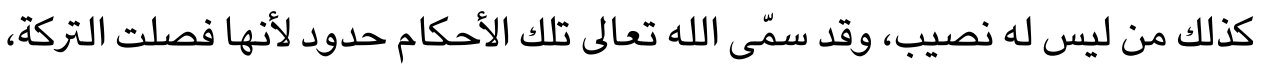
ومنعت الظلم وحفظت للأرحام علاقاتهم وودهم، فسبحان الحكيم الخبير. 


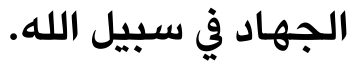

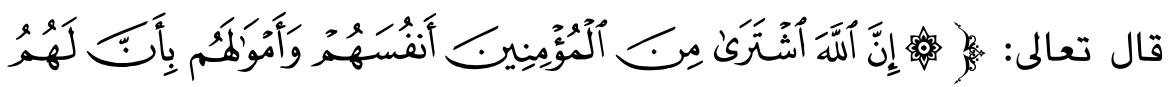

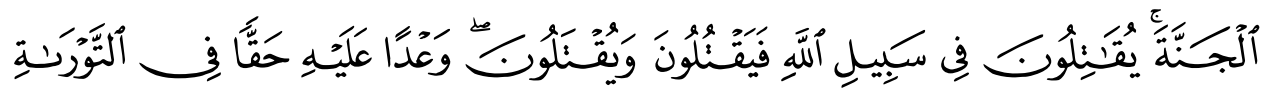

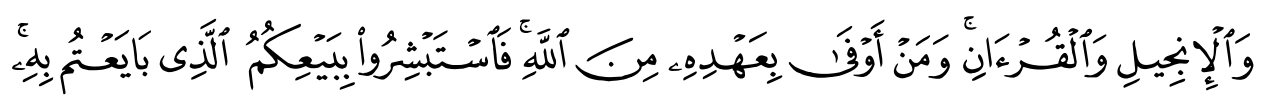

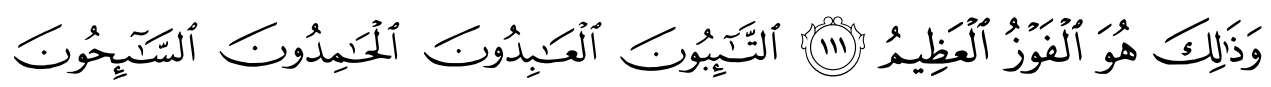

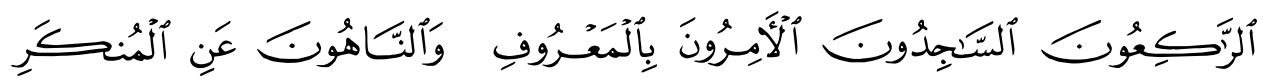

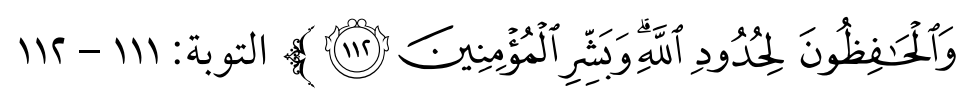

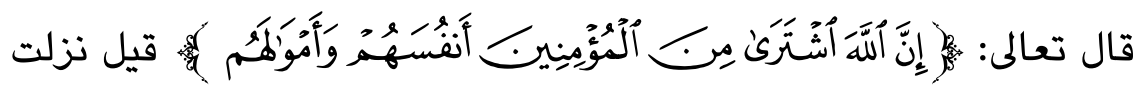
في بيعة العقبة، وحكمها عام في كل مؤمن مجاهد في سبيل الله إلى يوم القيامة. قال التال

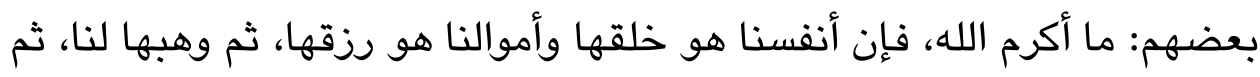

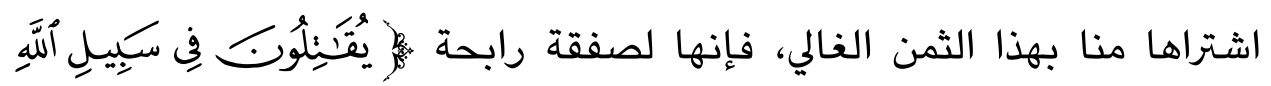

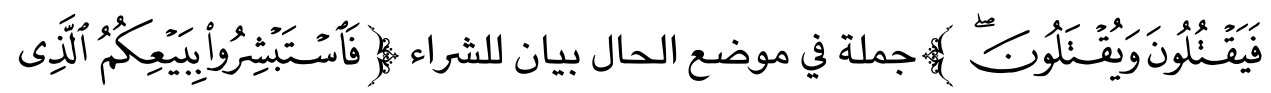

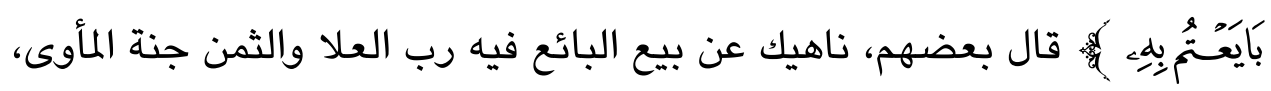

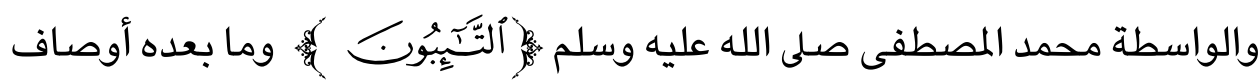
للمؤمنين الذين اشترى الله منهم أنفسهم وأموالهم تقديره: هم التائبون، السائحون

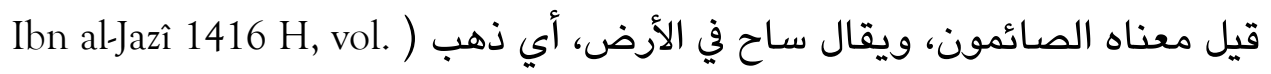
. $(1,348$

وجاء في فتح القدير: لما شرح فضائح المنافقين وقبائحهم بسبب تخلفهم

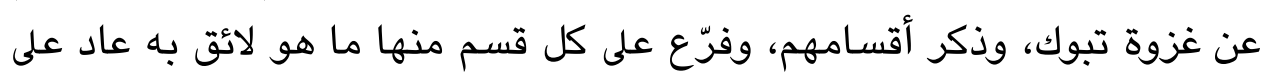

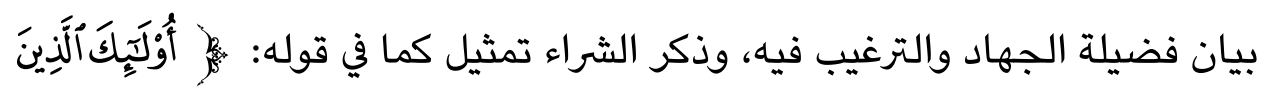




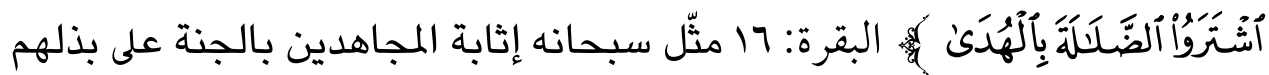

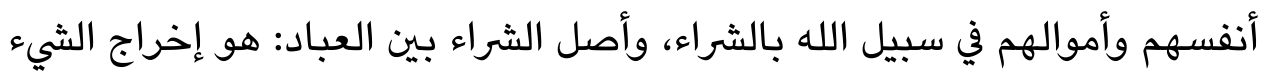

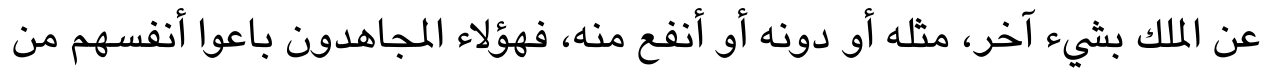

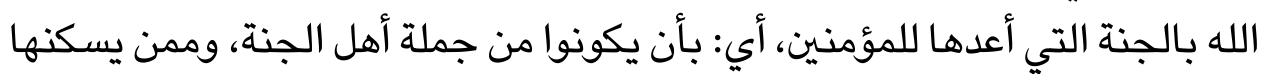

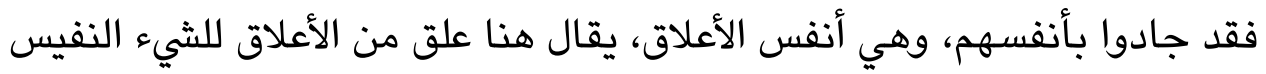
.(Ibn Fâris 1399 H, vol. 4, 128) وجاد الله عليهم بالجنة، وهي أعظم ما يطلبه العباد، ويتوسلون إليه بالأعمال، والمراد بالأنفس هنا: أنفس المجاهدين، وبالأموال ما ينفقونه في الجهاد. قوله:

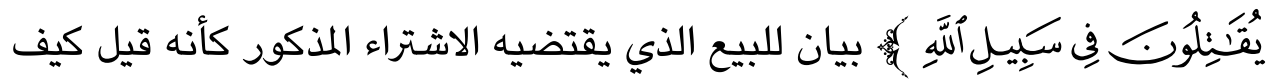
يبيعون أنفسهم وأموالهم بالجنة؟ فقيل: يقاتلون في سبيل الله، ثم بين هذه المقاتلة

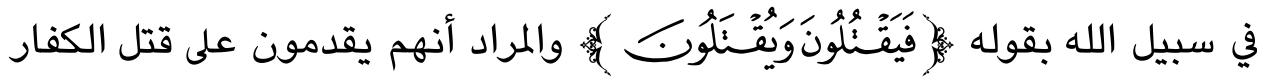

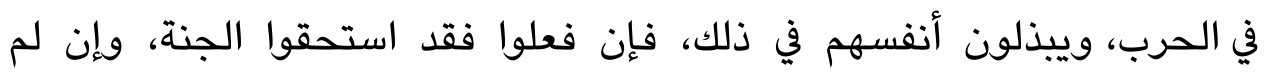

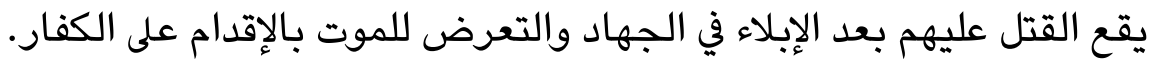

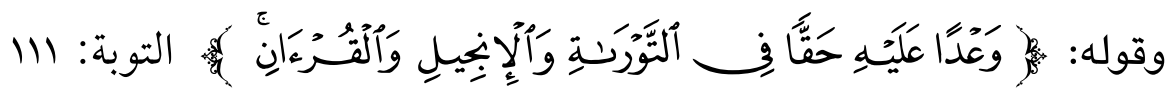
إخبار من الله سبحانه أن فريضة الجهاد واستحقاق الجنة بها قد ثبت الوعد بها

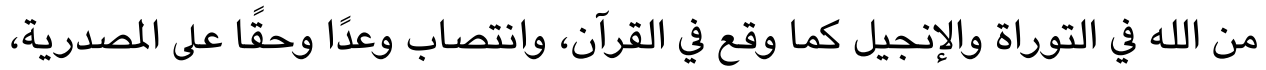
أو الثاني نعت للأول، وفي التوراة متعلق بمحذوف، ألي التي وعدًا ثابتًا فيها.

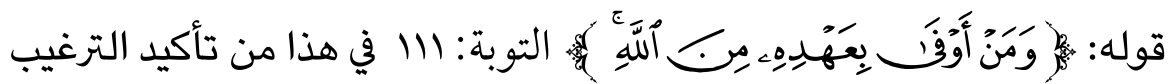
للمجاهدين في الجهاد، والتنشيط لهم على بذل الأنفس والأموال مالا يخفى، فإنه أولاًا

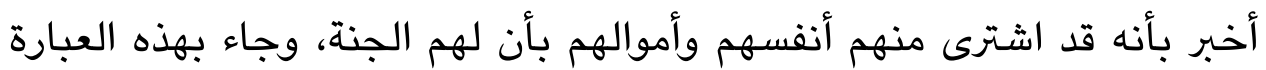

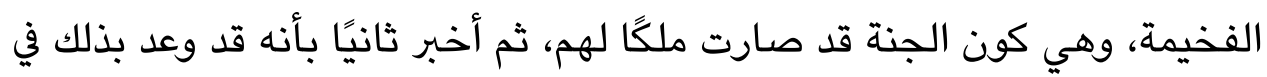

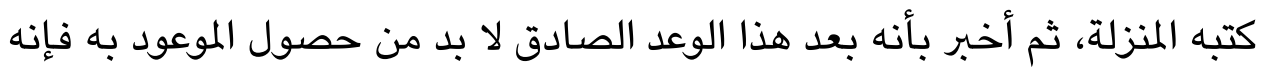
لا أحد أوفى بعهده من الله سبحانه، وهو صادق التهد الوعد لا يخلف الميعاد، ثم زادهم 


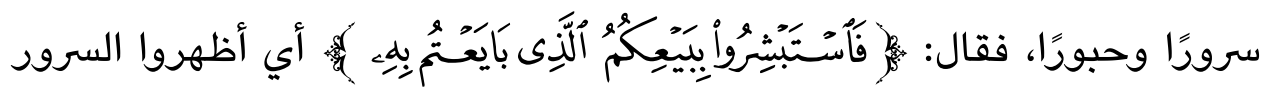

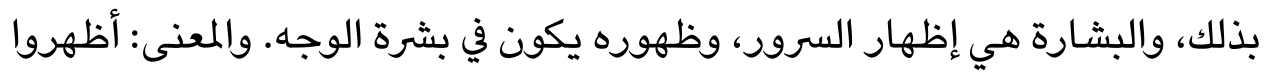

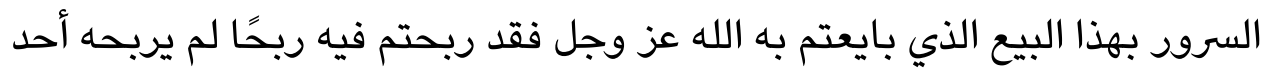
من الناس إلا من فعل مثل فعلكم (al-Shawkânî 1414 H, vol. 2, 464).

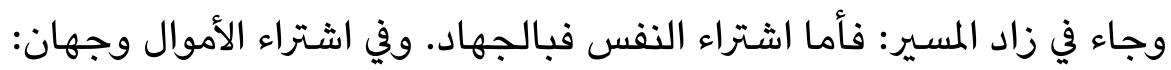

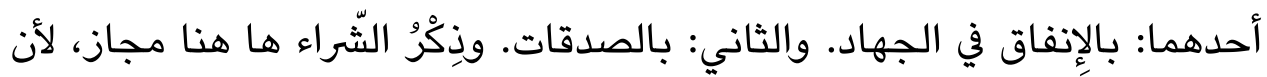

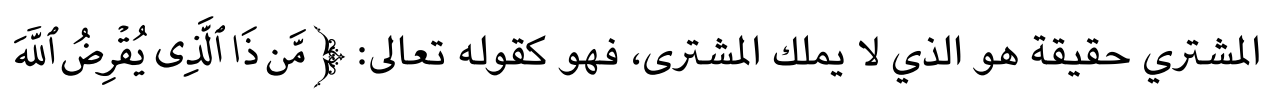

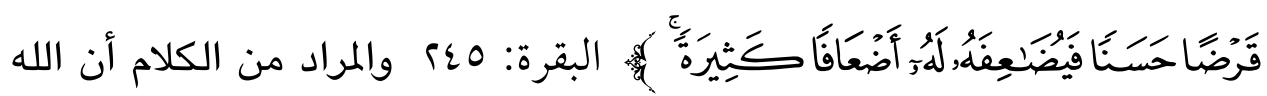

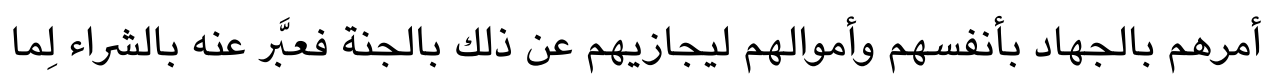

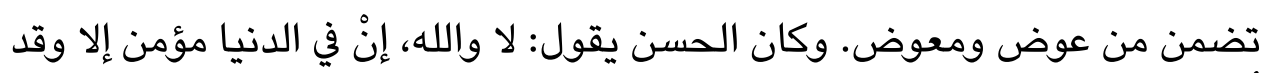

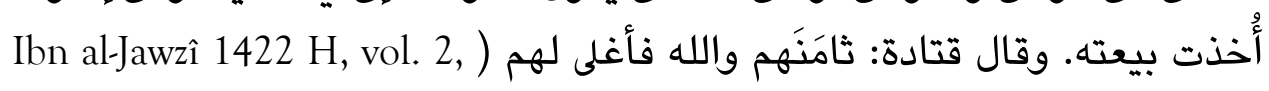
. (302

ومن صفات هؤلاء المؤمنين الذين لهم البشارة بدخول الجنة أنهم

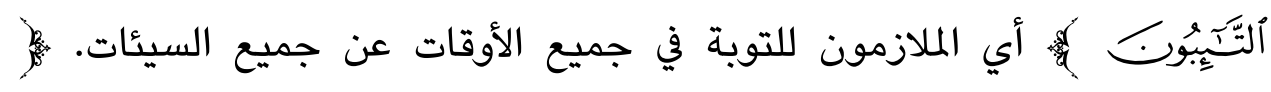

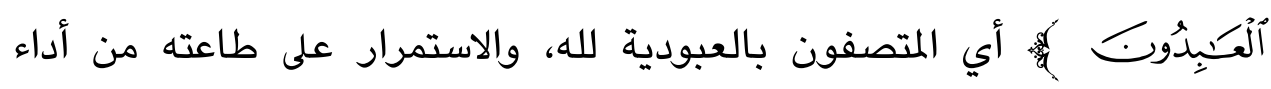

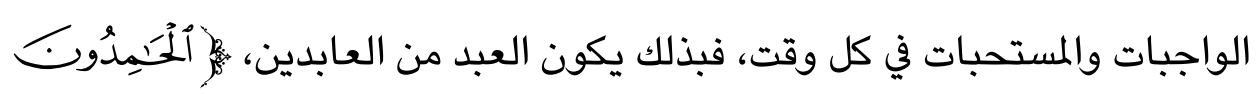

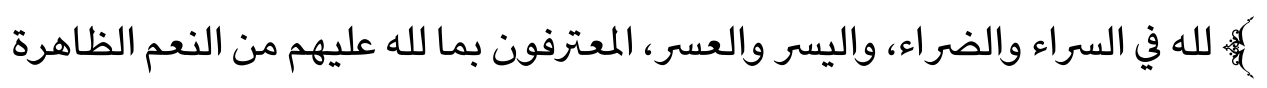

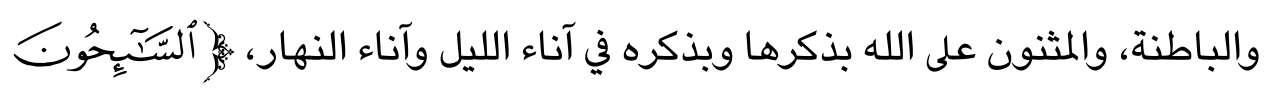
جإح فسرت السياحة بالصيام، أو السياحة في طلب العلم، وفسرت بسياحة القلب في

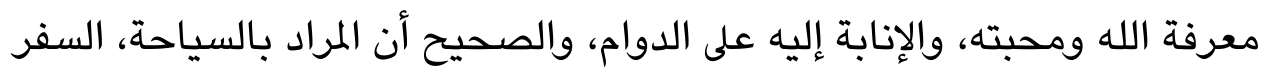

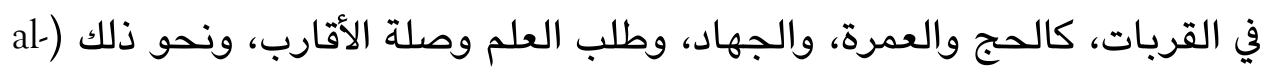
(Sadî 1420 H, 353 
وخصا بالذكر لما فيهما من الدلالة على التواضع والعبودية والتذلل لله سبحانه.

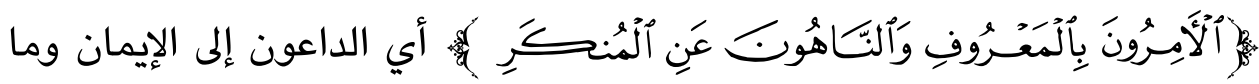
يتبعه من أعمال البر والخير، والناهون عن الشرك وما بسبيله من المعاصي والسيئات.

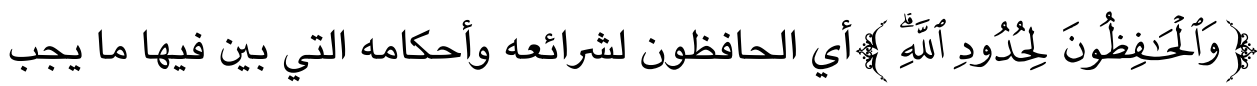
على المؤمنين اتباعه وما يحظر عليهم فعله منها، وكذا ما يجب على أملى أئمة المسلمين

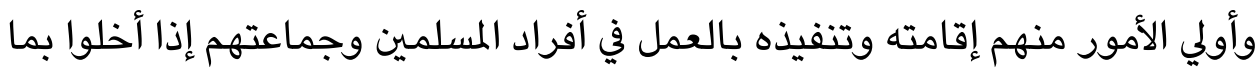

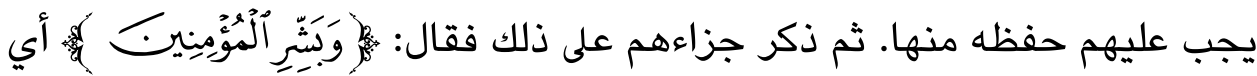
ويشر أيها الرسول المؤمنين المتصفين بهذه الصفات بخيري الدنيا والآخرة. وخصت

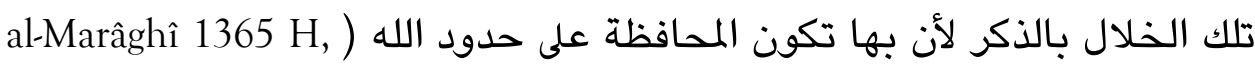
.(vol. 11, 34

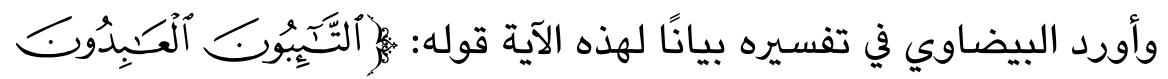

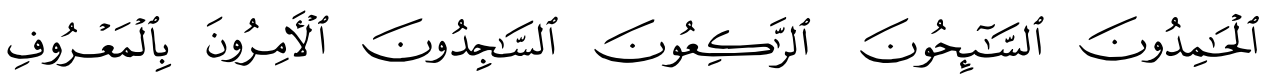

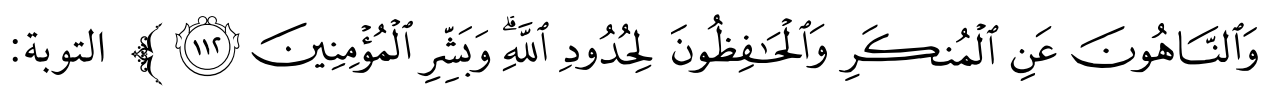

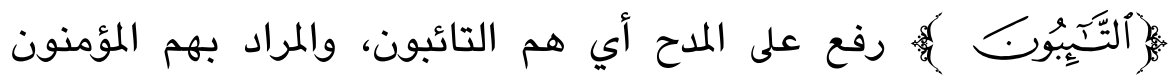

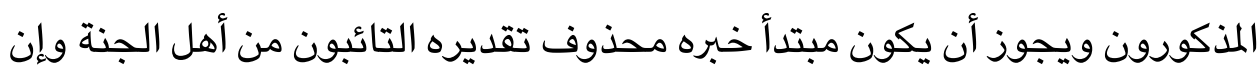
لم يجاهدوا لقوله: عن الكفر على الحقيقة هم الجامعون لهذه الخصال. وقرئ بالياء نصبًا على المدح أو

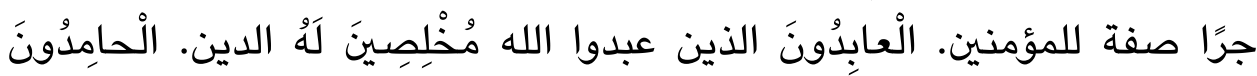
لنعمائه أو لما نابهم من السراء والضراء. السَّائِحُونَ الصائمون كما ورد في في الأثر:

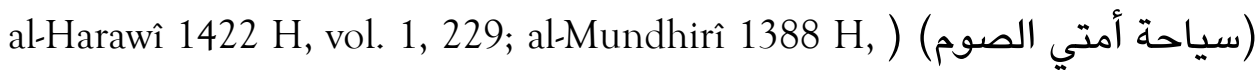
(vol. 1, 258 
al-) إلى الاطلاع على خفايا الملك والملكوت، أو السائحون للجهاد أو لطلب العلم .(Bayḍâwî 1418 H, vol. 3, 99

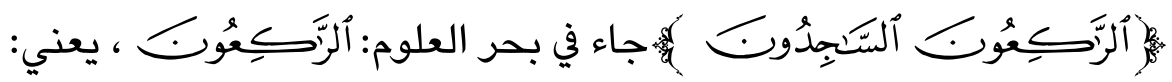
الذين يحافظون على الصلوات السَّاجدُونَ، الذين يسجدون لله تعالى في الصلوات.

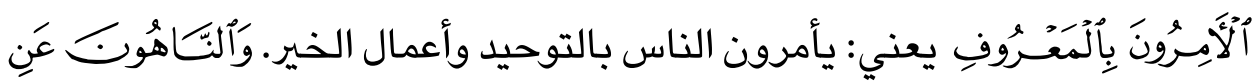

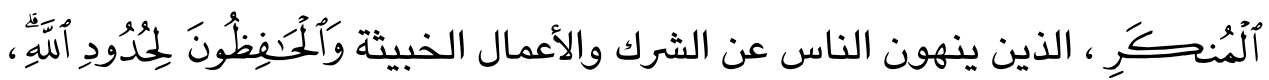
يعني: العاملين بما فرض الله عليهم (al-Samarqandî n.d., vol. 2, 90).

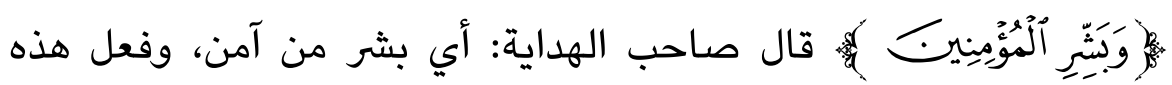

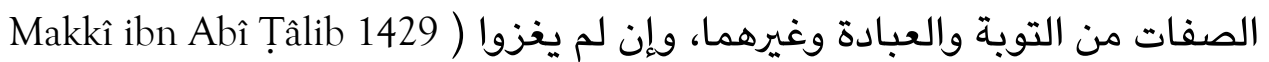
.(H, vol. 4, 3169 وهي هنا جاءت بمعنى عام عبرت عنه صفات أهل الإيمان من التوية والحمد والعبودية لله وإقامة الصلاة والأمر بالمعروف النهي عن المناءت المنكر فهذه هي حدود الله

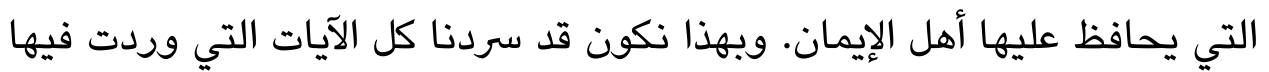

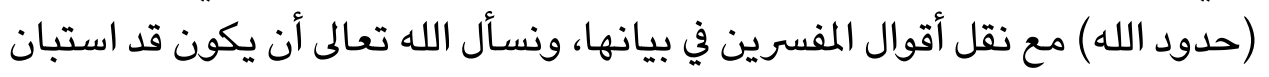
المعنى الذي قصدناه، وتحقق هدف البحث.

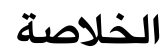

ويعد سرد البيانات، والوقوف على المعطيات، يورد الباحث أهم النتائج التي

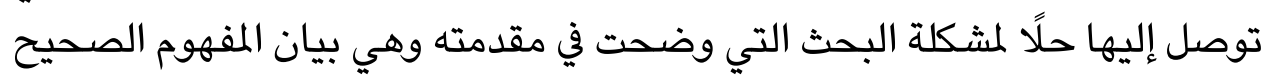
لحدود في القرآن الكريم، وتصحيح الفهم الخاطئ السائد عنها عند كثير من الناس.

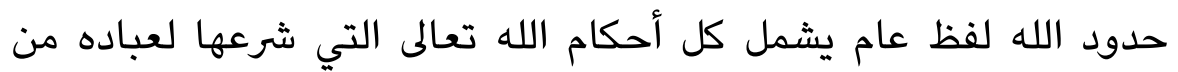
المأمورات والمنهيات، والعقويات. أكثر سورة ورد فيها ذكر (حدود اللهـ هي سورة

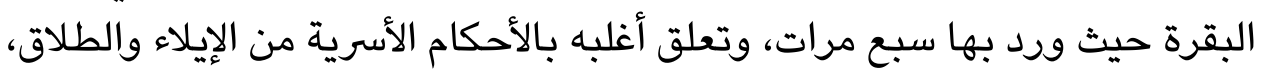
والعدة، وإباحة معاشرة الزوجة في ليالي رمضان، وجواز الخلع وغيره من الأحكام. 
لم يرد في القرآن الكريم لفظ حدود الله في الكلام عن العقويات الحدية كحد الزنا

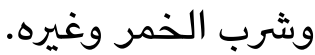
تطبيق حدود الله ليس قاصرًا فقط على العقويات الحدية كما يفهم كثير من الناس، ولكن إذا طبقنا أحكام الزواج من الطلاق والإيلاء والظهار والمعاشرة بالمعروف وأجزنا الخلع حقًا للزوجات فنحن نقيم حدود الله، وإذا عملنا بما أمرنا

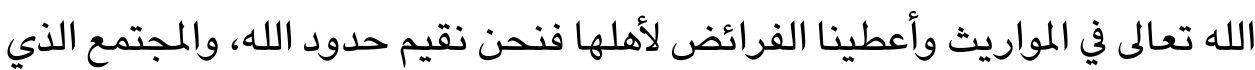

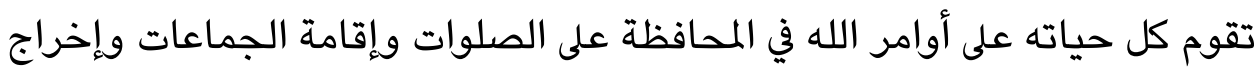
الزكاة فهو مقيم لحدود الله.

ليس صحيحًا أن نقول تأجيل حدود الله فحدود الله هي شرعه وكل ما وجب

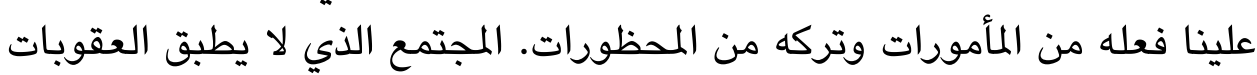

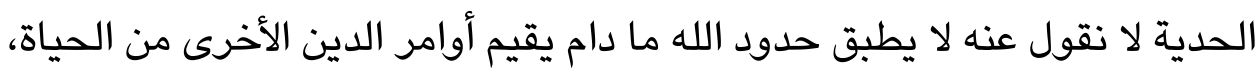

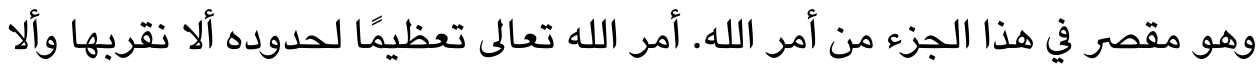

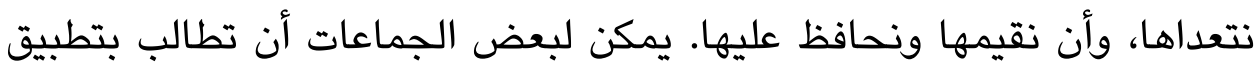

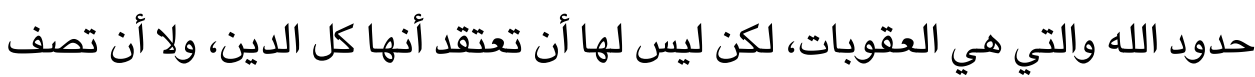

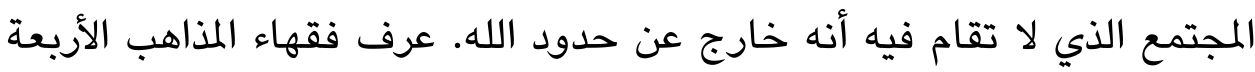
الحدود بمعنى العقويات الحدية لأنهم أرادوا تفصيل الأحكام الواردة فيها وليس اليس الهاء قصرًا لمعناهـا.

وأخيرًا أوصي من بعدي من الباحثين أن يكتبوا في هذا الموضوع والذي ما زال

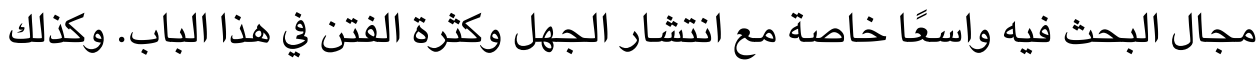

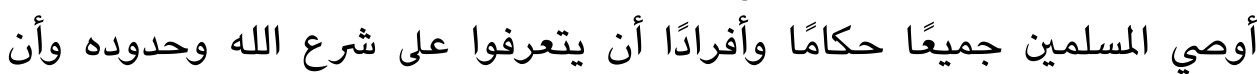

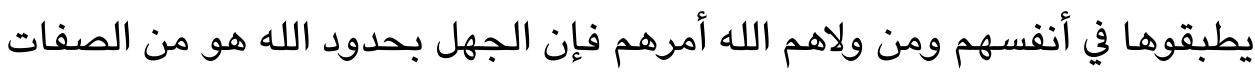
التي ذمها الله تعالى كما مر بنا سابقا في وصف ولاهف الإعراب.

\section{References}

"Abd al-Ghaffâr. n.d. "Muhimmât fî Aḥkâm al-Mawârîth - Fạ̣l 'Ilm alMawârîth."

https://audio.islamweb.net/audio/index.php?page=FullContent\&au dioid=179094\& page $=$ FullContent\& audioid=179094 (June 23, 2020) 
Abdulla, Dhahir M. 2019. "A Window on The Aplication of Islamic Law." Ahl Al-Bayt Jurnal 1(23): 567-82.

al-Asfahânî, al-Husayn ibn Muhammad al-Râghib. 1420 H. Tafsîr al-Râghib alAsfahânî. Tanta: Kulliyat al-Adab Jami'at Tanta.

al-Ba'lî, Muḥammad ibn Abî al-Fatḥ ibn Abî al-Faḍl. 1981. al-Muṭli' 'alâ Abwâb al-Fiqh. Beirut: al-Maktab al-Islâmî.

al-Bayḍ̂wî, 'Abd Allâh ibn 'Umar. 1418 H. Anwâr al-Tanzîl wa Asrâr al-Ta'wîl. Beirut: Dâr Ihyyâ' al-Turâth al-'Arabî.

al-Bukhârî, Muhạmmad ibn Ismâ'îl. 1422 H. Sahîh al-Bukhârî. Beirut: Dâr Ṭûq al-Najâh.

al-Dârquṭnî, Abû al-Hasan 'Alî ibn 'Umar. 1424 H. Sunan al-Dârqutnî. Beirut: Mu'assat al-Risâlah.

al-Farâhîdî, al-Khalîl ibn Aḥmad. n.d. al-Ayn. Beirut: Dâr wa Maktabat alHilâl.

al-Fayrûzâbâdî, Muḥammad ibn Ya'qûb ibn Muhammad ibn Ibrâhîm alShayrâzî. 1996. Bașâir Dhawî al-Tamyîz fî Latâiif al-Kitâb al'Azîz. Cairo: Lajnat Ihyầ' al-Turâth al-Islâmî.

al-Ḥanbali, 'Umar ibn 'Alî ibn 'Âdil. 1418 H. al-Lubâb fî 'Ulûm al-Kitâb. Beirut: Dâr al-Kutub al-'Ilmiyah.

al-Hararî, Muhammad al-Amîn. 1421 H. Hadẩiq al-Rûh wa al-Rayhân. Beirut: Dâr Ṭûq al-Najâh.

al-Harawî, 'Alî ibn Sultân Muhammad Abû al-Ḥasan Nûr al-Dîn. 1422 H. Mirqât al-Mafâtiḥ Sharh Mishkât al-Maṣâbih. Beirut: Dâr al-Fikr.

Ibn 'Ajîbah, Abû al-Abbâs Aḥmad ibn Muḥammad. 1419 H. al-Baḥr al-Murîd fî Tafsîr al-Qur'ân al-Majîd, ed. Ahmad 'Abd Allâh al-Qurashî Ruslân. Cairo: al-Nâshir Hasan 'Abbâs Zakî.

Ibn al-Athîr, al-Mubârak ibn Muhammad ibn Muḥammad al-Jazarî. 1399 H. al-Nihâyat fî Gharîb al-Hadîth wa al-Athar. Beirut: al-Maktabat al'Ilmiyah.

Ibn al-Jawzî, Abû al-Faraj 'Abd al-Raḥmân ibn Abî al-Ḥasan 'Alî ibn Muhammad. 1422 H. Zâd al-Masîr fì 'Ilm al-Tafsîr. Beirut: Dâr al-Kitâb al'AArabî. 
Ibn al-Jazî, Abû al-Qâsim Muḥammad ibn Aḥmad al-Kalabî. 1416 H. al-Tashîl li 'Ulûm al-Tanzîl. Beirut: Shirkat Dâr al-Arqam ibn Abî al-Arqam.

Ibn Durayd, Abû Bakr Muhammad ibn al-Hasan al-Azdî. 1987. Jamharat alLughah. Beirut: Dâr al-'Ilm al-Malâyîn.

Ibn Fâris, Muhammad ibn Fâris al-Qazwaynî. 1399 H. Mu'jam Maqâyis alLughah. Beirut: Dâr al-Fikr.

Ibn Manzûr, Muhammad ibn Mukarram. 1414 H. Lisân al-Arab. Beirut: Dâr Șâdir.

Ismail, Wan Nor Hana Wan et al. 2020. "Hudud: The Right of Allah SWT in Perspective of Punishment for Adultery." Journal of Critical Reviews 7(8): 789-92.

DOI: $10.31838 /$ jcr.07.08.169

al-Jawharî, Ismâ'îl ibn Hammâd. 1407 H. al-Sihâh Tâj al-Lughah wa Sihạh al'Arabiyah. Beirut: Dâr al-'Ilm al-Malâyîn.

al-Jawziyah, Muḥammad ibn Abî Bakr Ibn al-Qayyim. 1410 H. al-Tafsîr alQayyim. Beirut: Dâr wa Maktabat al-Hilâl.

al-Juwaynî, 'Abd al-Malik ibn Yûsuf ibn Muhammad. 1428 H. Nihâyat alMațlab fî Dirâsat al-Madhhab, ed. 'Abd al-Aẓ̂m Maḥmûd al-Dîn. Jaddah: Dâr al-Minhâj.

al-Khatîib, 'Abd al-Karîm. n.d. al-Tafsîr al-Qur'ânî li al-Qur'ân. Cairo: Dâr alFikr al-'Arabî.

Makkî ibn Abî Ṭâlib, Abû Muhammad Ḥamûs ibn Muhamammad ibn Mukhtâr al-Qaysî al-Qayruwânî. 1429 H. al-Hidâyat ilâ Bulûgh al-Nihâyah. Sharjah UEA: Majmû'ât Buhụth al-Kitâb wa al-Sunnah.

Muslim, Mustafâ et al. 1431 H. al-Tafsîr al-Mawdî̀ î li Suwar al-Qur'ân al-Karîm. Sharjah UEA: al-Dirâsat al-'Ulyâ Jâmi'at Shârqah.

al-Marâghî, Ahmad ibn Muṣtafâ. 1365 H. Tafsîr al-Marâghî. Egypt: Shirkat Maktabat wa Maṭba'ih Musțafâ al-Bâbî al-Ḥalabî wa Awlâdihî.

al-Mâwardî, Abû al-Ḥasan 'Alî ibn Muḥammad ibn Muhammad ibn Habîb al-Bașrî. n.d. Tafsîr al-Mâwardî. Beirut: Dâr al-Kutub al-'Ilmiyah.

al-Mâwardî, Abû al-Ḥasan 'Alî ibn Muḥammad ibn Muḥammad ibn Habîb al-Bașrî. 1999. al-Hâûi al-Kabîr. Beirut: Dâr al-Kutub al-'Ilmiyah. 
al-Mundhirî, Abû Muhammad Zakî al-Dîn 'Abd al-'Aẓ̂̃m ibn 'Abd al-Qawî ibn 'Abd Allâh. 1388 H. al-Tarhîb wa al-Targhîb min al-Hadîth al-Sharîf. Egypt: Maktabat Musțafâ al-Bâbî al-Hạalabî.

Okon, Etim E. 2014. "Hudud Punishment in Islamic Criminal Law." European Scientific Journal 10(14): 227-38.

al-Qurashî, Ismâ'îl ibn 'Umar. 1420 H. Tafsîr al-Qur'ân al-Ažim. Beirut: Dâr al-Tî̉bat li al-Nashr wa al-Tawzî‘.

al-Qurțubî, Abû 'Abd Allâh Muḥammad ibn Aḥmad. 1384 H. al-Jâmi' li Ahkâm al-Qur'ân. Cairo: Dâr al-Kutub al-Mișriyah.

al-Râzî, Muhammad ibn 'Umar Fakhr al-Dîn. 1420 H. Mafâtih al-Ghayb. Beirut: Dâr Ihyyâ' al-Turâth al-'Arabî.

al-Ṣâbûnî, Muhammad 'Alî. 1400 H. Rawâ'i' al-Bayân fî Tafsîr Ayât al-Ahkâm. Damascus: Maktabat al-'Azâlî Mu'assasat Manâhil al-'Irfân.

al-Ṣabûnî, Muhammad 'Alî. 1417 H. Safwat al-Tafâsir. Cairo: Dâr al-Ṣâbûnî li al-Ṭibâ'at wa al-Tawzî‘.

al-Ṣâwî, Aḥmad ibn Muḥammad. 1372 H. Balghah al-Sâlik li Aqrab al-Masâlik. al-Halabî: Maktabat Musțafâ al-Bâbî al-Ḥalabî.

al-Sa 'dî, 'Abd al-Raḥmân. 1420 H. Taysîr al-Karîm al-Raḥmân. Beirut: Mu'assat al-Risâlah.

al-Samarqandî, Abû al-Layth Nașr ibn Muhammad ibn Ahmad ibn Ibrâhîm. n.d. Bahr al-'Ulûm (Tafsîr al-Samarqandî). Beirut: Dâr al-Kutub al'Ilmiyah.

al-Sarakhsî, Muhạammad ibn Ahmad ibn Abî Sahl Shams al-A'immah. 1993. al-Mabsût. Beirut: Dâr al-Ma'rifah.

al-Shawkânî, Muhạmmad ibn 'Alî ibn Muhammad. 1414 H. Fath al-Qadîr. Dâr al-Kalim al-Ṭayyib.

al-Suyûṭ̂i, 'Abd al-Raḥmân. 1418 H. al-Muzhir fî̀ 'Ulûm al-Lughah wa Anwâ' 'hhâ. Beirut: Dâr al-Kutub al-'Ilmiyah.

al-Ṭabarî, Muhammad ibn Jarîr. 1420 H. Jâmi“ al-Bayân 'an Ta'wîl al-Qur'ân. Beirut: Mu'assat al-Risâlah. 
Umam, Fawaizul. 2019. "Ideological Involution of The Islamists." Ulul Albab: Jurnal Studi Islam 20(1): 25-45.

DOI: https://doi.org/10.18860/ua.v20i1.5714

al-Wâhịîi, Abû al-Ḥasan 'Alî ibn Aḥmad ibn 'Alî. 1430 H. al-Tafsîr al-Basît. Saudi Arabia: 'Imârat al-Baḥth al-'Ilmî bi Jâmi'at Muhạmmad ibn Su'ûd al-Islâmiyah.

al-Zuhaylî, Wahbah. n.d. Fiqh al-Islâm wa Adillatuhû. Damascus: Dâr al-Fikr. 